\title{
Quantifying sources, transport, deposition, and radiative forcing of black carbon over the Himalayas and Tibetan Plateau
}

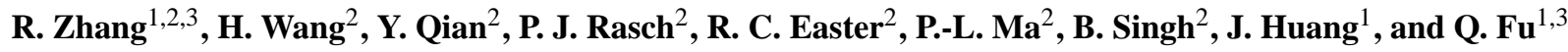 \\ ${ }^{1}$ Key Laboratory for Semi-Arid Climate Change of the Ministry of Education, College of Atmospheric Sciences, \\ Lanzhou University, Lanzhou 730000, Gansu, China \\ ${ }^{2}$ Atmospheric Sciences and Global Change Division, Pacific Northwest National Laboratory (PNNL), \\ Richland, WA 99352, USA \\ ${ }^{3}$ Department of Atmospheric Sciences, Box 351640, University of Washington, Seattle, WA 98195, USA \\ Correspondence to: H. Wang (hailong.wang@pnnl.gov)
}

Received: 25 October 2014 - Published in Atmos. Chem. Phys. Discuss.: 7 January 2015

Revised: 11 May 2015 - Accepted: 16 May 2015 - Published: 8 June 2015

\begin{abstract}
Black carbon (BC) particles over the Himalayas and Tibetan Plateau (HTP), both airborne and those deposited on snow, have been shown to affect snowmelt and glacier retreat. Since BC over the HTP may originate from a variety of geographical regions and emission sectors, it is essential to quantify the source-receptor relationships of $\mathrm{BC}$ in order to understand the contributions of natural and anthropogenic emissions and provide guidance for potential mitigation actions. In this study, we use the Community Atmosphere Model version 5 (CAM5) with a newly developed source-tagging technique, nudged towards the MERRA meteorological reanalysis, to characterize the fate of $\mathrm{BC}$ particles emitted from various geographical regions and sectors. Evaluated against observations over the HTP and surrounding regions, the model simulation shows a good agreement in the seasonal variation in the near-surface airborne $\mathrm{BC}$ concentrations, providing confidence to use this modeling framework for characterizing $\mathrm{BC}$ source-receptor relationships. Our analysis shows that the relative contributions from different geographical regions and source sectors depend on season and location in the HTP. The largest contribution to annual mean $\mathrm{BC}$ burden and surface deposition in the entire HTP region is from biofuel and biomass (BB) emissions in South Asia, followed by fossil fuel (FF) emissions from South Asia, then FF from East Asia. The same roles hold for all the seasonal means except for the summer, when East Asia FF becomes more important. For finer receptor regions of interest, South Asia BB and FF have the largest impact on $\mathrm{BC}$ in the Himalayas and central Tibetan Plateau, while East
\end{abstract}

Asia FF and BB contribute the most to the northeast plateau in all seasons and southeast plateau in the summer. Central Asia and Middle East FF emissions have relatively more important contributions to $\mathrm{BC}$ reaching the northwest plateau, especially in the summer. Although local emissions only contribute about $10 \%$ of BC in the HTP, this contribution is extremely sensitive to local emission changes. Lastly, we show that the annual mean radiative forcing $\left(0.42 \mathrm{~W} \mathrm{~m}^{-2}\right)$ due to $\mathrm{BC}$ in snow outweighs the $\mathrm{BC}$ dimming effect $\left(-0.3 \mathrm{~W} \mathrm{~m}^{-2}\right)$ at the surface over the HTP. We also find strong seasonal and spatial variation with a peak value of $5 \mathrm{~W} \mathrm{~m}^{-2}$ in the spring over the northwest plateau. Such a large forcing of BC in snow is sufficient to cause earlier snow melting and potentially contribute to the acceleration of glacier retreat.

\section{Introduction}

Black carbon (BC) is a distinct type of carbonaceous particulate matter mainly emitted from the incomplete combustion of fossil fuels, biofuels, and biomass burning. It is the dominant insoluble light-absorbing particulate species, both in the atmosphere and after deposition on snow and ice. In addition to its impact on air quality, $\mathrm{BC}$ plays a unique and important role in the climate system through its effect on radiation, clouds, and snow albedo, and associated feedbacks that modify atmospheric circulation patterns and/or accelerate the snowmelt and glacier retreat in the Arctic and across 
the midlatitudes of the Northern Hemisphere (Bond et al., 2013).

Modeling studies (e.g., Hansen et al., 2005; Qian et al., 2011) indicate that the climate efficacy of BC in snow is much greater than efficacy of carbon dioxide or other anthropogenic forcers owing to a sequence of positive feedback mechanisms (Warren and Wiscombe, 1980, 1985; Conway et al., 1996; Hansen and Nazarenko, 2004; Jacobson, 2004; Flanner et al., 2007; Ye et al., 2012; Hadley and Kirchstetter, 2012; Doherty et al., 2014). Flanner et al. (2009) demonstrated that the global annual BC snow-albedo effect (darkening) outweighs the aerosol (BC and organic matter) dimming effect (i.e., reduced the downwelling irradiance reaching the surface) by a factor of about 6 . The snow/ice-covered Himalayas and Tibetan Plateau (HTP) region is more prone to these $\mathrm{BC}$ effects than other regions because of the surrounding two major BC source regions, East Asia and South Asia, at present and likely in the future (e.g., Bond et al., 2007; Ohara et al., 2007; Xu et al., 2009; Lamarque et al., 2010; Menon et al., 2010).

The HTP, often referred to as the "third pole", has received much less scientific attention than the polar regions (Qiu, 2008), although it is the highest and largest plateau and stores one of the largest ice masses of the Earth system. The HTP also has a large area of seasonal and permanent snow cover and represents the most sensitive and visible indicator of climate change with its unique location for complex interactions among the atmosphere, hydrosphere, and cryosphere (e.g., Pu et al., 2007; Xu et al., 2009; Yao et al., 2012). The glaciers and the associated snowmelt over the HTP have a great potential to modify the regional hydrology and to trigger natural hazards that impact a large portion of the population in and around the region (e.g., Barnett et al., 2005; Singh and Bengtsson, 2004; Xu et al., 2008; Kaser et al., 2010; Immerzeel et al., 2010; Yao et al., 2012; Bolch et al., 2012). The HTP also exerts profound influences on atmospheric circulation patterns and climate through mechanical and thermal effects due to its large area, highly elevated topography and geographical location in the Earth system (Yeh et al., 1957; Manabe and Terpstra, 1974; Ye and Gao, 1979; Yanai et al., 1992; Ye and Wu, 1998; Wu et al., 2012). The HTP acts as a giant wall across the Eurasian continent that blocks cold outbreaks from high latitudes in winter and confines the winter monsoon to eastern and southern Asia, while in summer the HTP serves as a huge heat source through the strong surface sensible heating and latent heating over the central and eastern plateau (Wu et al., 2012).

The climate of the HTP is changing rapidly. For example, the surface sensible heat flux has weakened in recent decades, mainly due to global warming (Duan and $\mathrm{Wu}$, 2008). Observational evidence indicated that the surface air temperatures on the HTP have increased about $1.8^{\circ} \mathrm{C}$ over the past 50 years (Wang et al., 2008), while the large area at elevations above $4000 \mathrm{~m}$ has warmed at $0.3^{\circ} \mathrm{C}$ per decade in the past three decades (Xu et al., 2009). A number of re- cent studies reported that glaciers on the HTP have undergone widespread losses at an increasing rate in past decades (e.g., Qin et al., 2006; Li et al., 2008; Kang et al., 2010; Bolch et al., 2012) and have undergone accelerated retreat in recent years (Yao et al., 2007). The rapid warming and the accelerated glacier retreat have been primarily attributed to increasing greenhouse gases (e.g., Duan et al., 2006; Ren et al., 2006), but other factors may be partly responsible for the accelerated warming over the HTP, such as atmospheric heating by absorbing aerosols, land use changes, and reduction of snow albedo induced by light-absorbing impurities in snow (Kang et al., 2000; Prasad and Singh, 2007; Ramanathan et al., 2007; Flanner et al., 2007, 2009; Yasunari et al., 2010; Xu et al., 2009; Qian et al., 2011, 2015). Lau et al. $(2006,2010)$ proposed and demonstrated the elevated heat pump mechanism, whereby heating induced by airborne $\mathrm{BC}$ and dust absorption can strengthen local circulations and lead to a northward shift of the monsoon rain belt, widespread enhanced warming over the HTP, and accelerated snowmelt and glacier retreat. Previous observational and modeling studies have indicated that BC deposition on snow and ice, which has experienced a trend of rapid increase in recent years, has been a significant contributor to the early snowmelt and rapid glacier retreat over the HTP (e.g., Flanner et al., 2007, 2009; Ming et al., 2008; Xu et al., 2009; Kaspari et al., 2011; Menon, et al., 2010; Qian et al., 2011, 2015; Wang et al., 2015). Flanner et al. (2007) found that the largest regional annual mean forcing due to BC in snow is located in the HTP. Xu et al. (2009) and Lau et al. (2010) suggested that the BC in snow/ice may be partly responsible for the observed acceleration of glacier retreat in the HTP.

Understanding the role of $\mathrm{BC}$ in accelerating snow cover reduction and glacier retreat is becoming increasingly important. Over $60 \%$ of BC in the present-day atmosphere originates from anthropogenic activities (e.g., Bond et al., 2007; Lamarque et al., 2010). Reduction of emissions from BCrich sources represents a potential mitigation strategy to slow down present-day climate change because $\mathrm{BC}$ has a positive radiative forcing but a short atmospheric lifetime (Bond et al., 2013). Since BC over the HTP may originate from a variety of geographical regions and emission sectors, it is essential to quantify the source-receptor relationships of BC in order to understand the contributions of open-fire and anthropogenic emission sectors to BC over the HTP. This exercise is also essential to provide guidance for potential mitigation actions.

Some studies have used the conventional back-trajectory approach to identify possible source regions for both airborne $\mathrm{BC}$ and that deposited on snow and ice, by tracking air mass reaching sampling sites over the HTP (e.g., Ming et al., 2008, 2009; Cao et al., 2009; Bonasoni et al., 2010; Zhao et al., 2013; Zhang et al., 2013). Lu et al. (2012) developed a novel back-trajectory approach to analyze the origin of $\mathrm{BC}$ transported to the HTP during 1996-2010. They derived the overall transport characteristics of BC to the HTP and showed 
the spatial distribution of sources for BC reaching the HTP region based on a large set of 7-day back trajectories arriving at the given height (i.e., $500 \mathrm{~m}$ ) and receptor locations, $\mathrm{BC}$ emissions, and transport efficiencies. The statistical analysis of trajectories has good accuracy on short timescales for source regions with close proximity to the receptor, but this approach has limitations in determining contributions from distant sources to $\mathrm{BC}$ in the middle and upper troposphere that could contribute significantly to the total column burden but less to $\mathrm{BC}$ deposition and boundary-layer concentrations. Using the adjoint of the GEOS-Chem global chemical transport model, Kopacz et al. (2011) attempted to identify the originating locations of $\mathrm{BC}$ arriving at five glacier sites (i.e., five model grid cells as the receptors) in the HTP for year 2001. This method can provide a global distribution of emissions that directly contribute to BC concentrations at receptor locations. Note that the adjoint model results are not source attributions but rather the source-receptor sensitivities, which can be interpreted as the effectiveness of incremental changes to existing emissions in affecting BC at receptor locations. While the adjoint approach has the advantage of not predefining source regions, it does require performing separate simulations for each of the defined receptor regions.

In this study, we use an aerosol-climate model with a newly developed explicit source-tagging approach (Wang et al., 2014) to produce a detailed characterization of the fate of $\mathrm{BC}$ emitted from various geographical regions and sectors (e.g., fossil fuel, biofuel, and biomass burning emissions) and transport pathways to the HTP. In contrast to the back-trajectory and the adjoint approaches, the direct tagging method has the flexibility to do source attribution of $\mathrm{BC}$ mass mixing ratio at any model layer and the surface dry and/or wet deposition within a single simulation for any receptor regions. Section 2 describes the aerosol-climate model and the tagging method used in this study. Section 3 presents an evaluation of modeled BC surface concentrations and seasonal snow cover over the HTP region. The transport pathways and source attribution results are presented in Sect. 4. The radiative effects of $\mathrm{BC}$ in the atmosphere and of both $\mathrm{BC}$ and mineral dust in snow are compared in Sect. 5, followed by the summary and conclusions in Sect. 6 .

\section{Model configuration and experimental design}

\subsection{The CAM5 model and the source-tagging method}

We use the Community Atmosphere Model version 5 (CAM5; Neale et al., 2012), which is the atmospheric component of the Community Earth System Model version 1 (CESM1) (Hurrell et al., 2013). It includes relatively comprehensive representations of aerosols and clouds, and mechanisms for their interactions with each other and with climate (Gettelman et al., 2010; Liu et al., 2012). CAM5 employs a modal aerosol module (MAM) to represent aerosols in multiple log-normally distributed modes, with internal mixing assumed for aerosol species within each individual mode, including a three-mode standard representation (MAM3) and a more complex seven-mode representation (MAM7). The major difference between MAM3 and MAM7 related to carbonaceous aerosols lies in the treatment of aging. In MAM3, $\mathrm{BC}$ and primary organic matter (POM) particles are emitted into the accumulation mode, which also contains highly hygroscopic species such as sulfate and sea salt, while in MAM7, BC and POM are emitted into a primary carbon mode, which contains no other species. BC is hydrophobic upon emission, and thus the hygroscopicity of the primarycarbon-mode particles depends on the assumed hygroscopicity for POM. As more hygroscopic species (e.g., $\mathrm{H}_{2} \mathrm{SO}_{4}$ and $\mathrm{NH}_{3}$ ) condense onto the primary-carbon-mode particles, the particles become more hygroscopic and are gradually transferred into the MAM7 accumulation mode. The rate of transfer is controlled by uncertain aging parameters and the availability of gas precursors (Liu et al., 2012). In the accumulation mode of both MAM3 and MAM7, BC is internally mixed with other more hygroscopic species and is thus subject to wet scavenging and removal processes. During the transport from sources to remote regions, aerosols are removed too efficiently in the default CAM5 (Liu et al., 2012). Recently, H. Wang et al. (2013) revised some key processes associated with aerosol wet removal and convective transport, which significantly improved the vertical distribution of aerosols and their transport to remote regions such as the Arctic.

To better characterize the sensitivity of BC spatial distributions to emission uncertainties, Wang et al. (2014) implemented a direct source-tagging method in CAM5, whereby $\mathrm{BC}$ emitted from a number of independent source regions and/or sectors can be tagged and explicitly tracked within a single model simulation. This approach provides the quantitative characterization of source-receptor relationships for $\mathrm{BC}$ in any receptor region without perturbing emissions from individual BC source regions or sectors. In this study, we apply the $\mathrm{BC}$ tagging technique to the accumulation-mode $\mathrm{BC}$ in the MAM3 treatment. BC particles emitted from 16 geographical $\mathrm{BC}$ source regions and two emissions sectors (i.e., biomass burning and biofuel emissions and fossil fuel emissions) in each of the regions are tagged and explicitly tracked. Instead of using the global emissions from all sectors for the original one $\mathrm{BC}$ mass mixing ratio variable, the $32 \mathrm{regional} / \mathrm{sectoral}$ emissions provide sources to the respective tagged $\mathrm{BC}$ mass mixing ratio variables that are all added to the accumulation mode, including both interstitial and cloud-borne states. All physical and dynamic tendencies (e.g., transport, dry and wet removal) are calculated explicitly for the tagged $\mathrm{BC}$ mass mixing ratio variables in the same way as the original single $\mathrm{BC}$ mass mixing ratio. Also, when aerosol optical properties are calculated, all of the tagged $\mathrm{BC}$ mass mixing ratios contribute to the volume-mean refractive 
index of the accumulation mode that is used in the radiation calculation.

In addition to the free-running mode, CAM5 can also be configured in an offline mode, in which temperature, wind, surface fluxes (heat, moisture, and momentum), and pressure are constrained to agree closely with observations, while clouds and aerosol are allowed to evolve freely (Rasch et al., 1997; Lamarque et al., 2012; Ma et al., 2013). In this study, we run the CAM5 model in the offline mode with the direct $\mathrm{BC}$ source-tagging capability, including the improved representation of convective transport and wet removal of aerosols. We use the NASA Modern Era RetrospectiveAnalysis for Research and Applications (MERRA) reanalysis data set (Rienecker et al., 2011), using a horizontal resolution of $1.9^{\circ} \times 2.5^{\circ}$ and 56 vertical levels. The goal is to characterize the fate of $\mathrm{BC}$ emitted from various geographical regions and sectors, their transport pathways to the HTP, and their radiative forcing with seasonal variations. The simulation is performed for year 2001 with prescribed sea surface temperatures.

\subsection{BC source regions and sectors}

BC emission data sets have large uncertainties (e.g., Bond et al., 2013), and there are different inventories available for climate modeling. We use the present-day (i.e., year 2000) monthly mean emission inventories for BC provided by Lamarque et al. (2010). They were built for the climate model simulations in the Coupled Model Intercomparison Project Phase 5 (CMIP5) (Taylor et al., 2012) performed for the Fifth Assessment Report (AR5) of the Intergovernmental Panel on Climate Change (IPCC). The AR5 BC emissions being used in our CAM5 simulation include monthly varying elevated open-fire emissions (injection altitude up to $6 \mathrm{~km}$ ), and yearly constant surface emissions from shipping and from six sectors over land: agricultural waste burning, domestic, energy, industry, transportation, and waste treatment. These surface BC emissions sectors do not distinguish between biofuel and fossil fuel combustion. To prepare for the BC source sector tagging, we divide the total surface emissions into two broader sectors, biofuel and fossil fuel, by using the ratio of biofuel to biofuel plus fossil fuel at each model grid provided by Dentener et al. (2006). We then combine the biomass burning (open fire) emissions and surface biofuel emissions, hereafter referred to as the BB (biofuel and biomass) sector. The shipping emissions are combined with the fossil fuel emissions over land to form the FF (fossil fuel) sector. Note that emissions in the BB sector have seasonal variations (associated with the open-fire emissions) but the FF sector emissions used in this study have no seasonal variation at all.

The 16 geographical BC source regions (Fig. 1a) are defined using the definition of source/receptor regions by Work Plan (WP 2.1) of the Task Force on Hemispheric Transport of Air Pollution (http://iek8wikis.iek.fz-juelich.de/HTAPWiki/
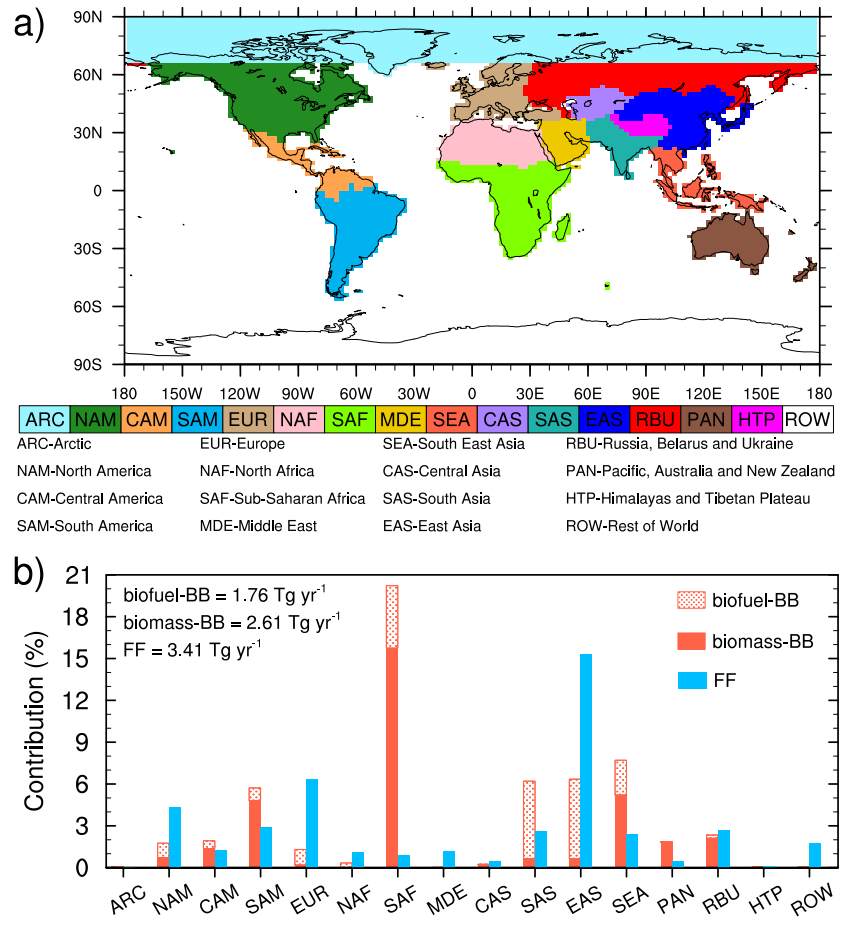

Figure 1. (a) Tagged source regions and (b) the respective percentage contributions to global annual mean $\mathrm{BC}$ emissions from the individual source regions and sectors (including biofuel, biomass burning, and fossil fuel). The global annual mean BC emission rate is $7.78 \mathrm{Tg} \mathrm{yr}^{-1}$, which is divided into the three sectors as indicated by the numbers in the upper-left corner.

WP2.1). They are ARC (Arctic), NAM (North America), CAM (Central America), SAM (South America), EUR (Europe), NAF (North Africa), SAF (Sub-Saharan Africa), MDE (Middle East), CAS (Central Asia), SAS (South Asia), EAS (East Asia), SEA (South East Asia), PAN (Pacific, Australia and New Zealand), RBU (Russia, Belarus and Ukraine), HTP (Himalayas and Tibetan Plateau), and ROW (rest of world).

Figure $1 \mathrm{~b}$ and Table $\mathrm{S} 1$ in the Supplement summarize the fractional contributions of $\mathrm{BC}$ emissions from the different source regions and sectors. The global annual mean $\mathrm{BC}$ emission rate is $7.78 \mathrm{Tg} \mathrm{yr}^{-1}$, with $56.2 \%$ (sum of the red bars) from BB emissions (33.6\% from fires and $22.6 \%$ from biofuel) and $43.8 \%$ (sum of the blue bars) from FF emissions. The two largest contributors are BB emissions from SAF (about $20 \%$ ) and FF emissions from EAS (about $15 \%$ ), followed by BB emissions from SEA (7.7\%), EAS $(6.4 \%)$, SAS $(6.2 \%)$, and SAM (5.7\%), as well as EUR FF $(6.4 \%)$ emissions. The geographical distributions of BC annual mean emission fluxes from BB and FF sectors for year 2000 are shown in Fig. S1 (in the Supplement). The global annual and seasonal mean lifetimes of BC emitted from the tagged source regions and sectors are summarized in Table S2. On global average, BB BC has a longer lifetime than FF BC in all seasons, especially in boreal winter (6.9 vs. 3.1 
days), due in part to higher open-fire emissions (in the BB sector) during local dry seasons. Another reason is that openfire emissions have initial injection heights of up to $6 \mathrm{~km}$, resulting in less removal below $6 \mathrm{~km}$. The availability of coemitted hygroscopic species that are internally mixed with $\mathrm{BC}$ in the accumulation mode of the MAM3 aerosol treatment also impacts the scavenging and wet removal rate of BC. This also in part explains the variability of BC lifetime among the different source regions and sectors. Regarding the seasonal cycle, BC emitted from the major source regions (e.g., SAF, EAS, SEA, SAS) has substantially lower lifetime in summer (JJA) than in the other seasons, likely due to relatively strong removal by the summer monsoon precipitation.

We use two metrics for quantifying source-receptor relationships and the sensitivity of $\mathrm{BC}$ in a receptor region to various sources following Wang et al. (2014), but we extend them to treat BB and FF sectors separately.

1. The fractional contribution of $\mathrm{BB}$ and $\mathrm{FF}$ emissions from source region $i$ to a BC property in receptor region $j$ (the entire HTP or a subset of it), $C_{i}^{\mathrm{BB}}$ or $C_{i}^{\mathrm{FF}}$, is defined as

$C_{i}^{\mathrm{BB}}=\frac{A_{i}^{\mathrm{BB}}}{A_{j}}, \quad C_{i}^{\mathrm{FF}}=\frac{A_{i}^{\mathrm{FF}}}{A_{j}}$,

where $A_{i}^{\mathrm{BB}}$ and $A_{i}^{\mathrm{FF}}$ are a BC property (e.g., mass mixing ratio, column burden, or deposition flux) in/over receptor region $j$ resulting from $\mathrm{BB}$ and FF emissions, respectively, in source region $i$, and $A_{j}=$ $\sum_{i=1}^{N}\left(A_{i}^{\mathrm{BB}}+A_{i}^{\mathrm{FF}}\right)$ represents the total BC property in the receptor region from all source regions $(N=16$ in this study) and sectors (BB and FF). Note that for BC properties such as column burden, surface mixing ratio, and deposition flux, the tagging method in CAM5 explicitly calculates how much is due to emissions from each source region and sector.

2. The efficiency of BB and FF emissions from source region $i$ in changing $\mathrm{BC}$ in a receptor region $j$ is defined as

$S_{i}^{\mathrm{BB}}=\frac{C_{i}^{\mathrm{BB}}}{\frac{E_{i}^{\mathrm{BB}}}{E_{\mathrm{tot}}}}, \quad S_{i}^{\mathrm{FF}}=\frac{C_{i}^{\mathrm{FF}}}{\frac{E_{i}^{\mathrm{FF}}}{E_{\mathrm{tot}}}}$,

where $C_{i}^{\mathrm{BB}}$ and $C_{i}^{\mathrm{FF}}$ are the fractional contribution defined in Eq. (1), $E_{i}^{\mathrm{BB}}$ and $E_{i}^{\mathrm{FF}}$ are the total $\mathrm{BB}$ and FF emission rates, respectively, in source region $i$, and $E_{\mathrm{tot}}=\sum_{i=1}^{N}\left(E_{i}^{\mathrm{BB}}+E_{i}^{\mathrm{FF}}\right)$ in Eq. (2) represents the global total emission rate. The efficiency metric $S_{i}^{\mathrm{BB}}$ or $S_{i}^{\mathrm{FF}}$ characterizes the sensitivity of aerosol properties in a receptor region to per unit (BB or FF) emissions in source region $i$. As noted in Wang et al. (2014), the efficiency is proportional to the metric of relative contribution per unit source region emission used by Shindell et al. (2008). Physically, the efficiency metric can be viewed as the efficiency of transport from a source region to the receptor region. This metric is perhaps of more interest to policymakers for the purpose of mitigation action, which is not the focus of this study but is worth mentioning.

\section{Model evaluation against available observations}

The CAM5 model has been evaluated in detail from different perspectives with available observations such as aerosol mass concentration, aerosol number concentration and size distribution, aerosol optical properties, cloud properties, aerosol deposition, and $\mathrm{BC}$ in snow over various regions in previous studies (Liu et al., 2012; H. Wang et al., 2013; Ma et al., 2013; Jiao et al., 2014; Lee et al., 2013; Qian et al., 2014). Because of the complex topography and meteorology of the HTP and the relatively coarse resolution of the global model, further model evaluation focusing on the HTP region is critical. Here we use near-surface atmospheric BC concentrations measured at a few HTP sites and the snow cover fraction retrieved from satellite to evaluate the CAM5 performance in the HTP.

\subsection{Atmospheric BC surface concentration}

There are seven remote sites that have surface measurements of seasonal BC aerosol concentrations available. The locations and elevations of the sites and the sampling time periods and observation methods are described in Table 1. Figure 2 shows the comparison of seasonal mean $\mathrm{BC}$ concentrations between observations and CAM5 results. Note that model results represent mean concentrations in the grid box that the sampling sites reside in and at the grid-mean elevation, which could deviate significantly from the sampling point near complex terrain. All sites have non-negligible amounts of $\mathrm{BC}$ in the near-surface air. The error bars indicate the intraseasonal and interannual variations if multiyear data were used for given season and site. However, the uncertainties of observed BC surface concentrations mainly originate from the large discrepancies between different measurement methods, the mixing of BC with other components (e.g., organic carbon and mineral dust) in the aerosol samples, and the sampling time and location (Bond et al., 2013; Petzold et al., 2013). BC surface concentrations over the various sites show strong seasonal variations, which are reasonably captured by the model. The modeled magnitude of BC concentrations has a good agreement with observations at some sites (e.g., Fig. 2b, d, g), but the model clearly overestimates BC at the Muztagh Ata site (Fig. 2a) and underestimates at the Lulang site (Fig. 2e). The large underesti- 
Table 1. List of sites for the observations of atmospheric BC surface concentrations used in this study to evaluate our model simulation.

\begin{tabular}{|c|c|c|c|c|c|c|c|}
\hline \multirow[t]{2}{*}{ Site } & \multirow{2}{*}{$\begin{array}{l}\text { Latitude } \\
\qquad\left({ }^{\circ} \mathrm{N}\right)\end{array}$} & \multirow{2}{*}{$\begin{array}{r}\text { Longitude } \\
\qquad\left({ }^{\circ} \mathrm{E}\right)\end{array}$} & \multicolumn{2}{|c|}{ Elevation (m) } & \multirow{2}{*}{$\begin{array}{r}\text { Sampling } \\
\text { time }\end{array}$} & \multirow{2}{*}{$\begin{array}{l}\text { Observation } \\
\text { method }\end{array}$} & \multirow[t]{2}{*}{ Contributor } \\
\hline & & & observation & model & & & \\
\hline Muztagh Ata & 38.3 & 75.0 & 4500 & 3497 & 2003-2006 & $\begin{array}{l}\text { Thermal optical } \\
\text { reflectance (TOR) }\end{array}$ & Cao et al. (2009) \\
\hline Hanle & 32.8 & 79.0 & 4250 & 4862 & 2009-2010 & Aethalometer & Babu et al. (2011) \\
\hline Manora Peak & 29.4 & 79.5 & 1950 & 1409 & 2005-2008 & $\begin{array}{l}\text { Thermal optical } \\
\text { transmittance (TOT) }\end{array}$ & Ram et al. (2010) \\
\hline NCO-P & 28.0 & 86.8 & 5079 & 4604 & 2006-2008 & $\begin{array}{l}\text { Multi-angle absorption } \\
\text { photometer (MAAP) }\end{array}$ & Marinoni et al. (2010) \\
\hline Lulang & 29.5 & 94.4 & 3300 & 3370 & 2008-2009 & TOR & Zhao et al. (2013) \\
\hline NCOS & 30.8 & 91.0 & 4730 & 4956 & 2006-2007 & TOR & Ming et al. (2010) \\
\hline QSSGEE & 39.5 & 96.5 & 4214 & 2748 & 2009-2011 & Aethalometer & Zhao et al. (2012) \\
\hline
\end{tabular}

mation (about $1000 \mathrm{~m}$; see Table 1) of the Muztagh Ata site elevation in the model, determined by the model grid resolution, could largely explain the overestimation of $\mathrm{BC}$ since $\mathrm{BC}$ concentrations have sharp decreases with height in this region. At the sites over the southern HTP (i.e., Hanle, Manora Peak, NCO-P, Lulang, and NCOS), the BC surface concentrations in the summer (JJA) are lower, mainly due to wet scavenging by more frequent precipitation and partly due to the minimal emissions from domestic heating and wildfires over the Himalaya foothills and Indo-Gangetic Plain (IGP) during the Indian summer monsoon season (Marinoni et al., 2010, 2013). Among all these sites, the largest BC surface concentrations occur at the Manora Peak site, which is closer to the major sources in South Asia, especially in the winter (DJF), when the model underestimates the concentrations by about $50 \%$. The high concentrations in winter at Manora Peak is mainly due to the dry winter monsoon conditions and increased transport of emissions from regional biomass burning, agricultural waste, and wood fuel burning from the IGP (e.g., Ram et al., 2010; Moorthy et al., 2013). The BC surface concentrations peak in the springtime (MAM) at Hanle, NCO-P, Lulang, and NCOS sites. This might be related to an increase in BB and/or FF emissions in the Indian Subcontinent, along with the higher regional boundary-layer top over the IGP during the springtime that may favor the transport of particles from the surface up to higher altitudes (e.g., Marinoni et al., 2010, 2013). Moreover, long-range transport of pollution emitted from distant regions like the Middle East, North Africa, or Europe (Marinoni et al., 2010) could further contribute to BC variability over the southern Himalayas, which will also be examined in this study. Part of the discrepancies between observations and model results can be attributed to the inherent difficulty in simulating the cloud/precipitation fields over the complex topography and subsequent wet removal of aerosols during the transport, but emission uncertainties (e.g., Bond et al., 2013) might play a primary role.

\subsection{Snow cover fraction}

It is important to evaluate the performance of model in simulating seasonal snow over this region in order to assess the importance of BC-in-snow effect. Figure 3 shows the CAM5 simulated seasonal and annual mean snow cover fraction (SCF) during year 2001, in comparison to observed mean SCF, derived from the Moderate Resolution Imaging Spectrometer (MODIS) (Hall et al., 2006) monthly mean of daily products at $0.05^{\circ}$ resolution. For a better comparison, the MODIS monthly mean SCFs are mapped to the CAM5 grid. The summer (JJA) season only includes July and August for both CAM5 and MODIS due to missing MODIS data in June 2001. To illustrate whether year 2001 can represent the average condition in terms of SCF, the MODIS SCF climatology (2000-2013) is also plotted. The overall SCF in HTP has very small difference between climatology and year 2001 in all seasons except for JJA, when SCF is notably higher over the northwest plateau for the climatology that included June SCF in the average. On average, SCF is about $5 \%$ (absolute amount) higher in June than in July and August. Over the 52 HTP grid cells, the CAM5 SCF is highly correlated spatially with that of MODIS (for both 2001 and 2000-2013) with the statistical confidence level greater than $99 \%$, except for summer (JJA), when the linear correlation is significant only at $80 \%$ level.

There are strong spatial and seasonal variations in SCF due to the complex terrain and seasonal variation in snowfall and melting. The SCF over the entire HTP reaches the maximum in the winter (DJF), while it decreases to almost none (less than $5 \%$ ) in July and August. Snow covers the western and southeastern plateau during the transition seasons (MAM and SON). The CAM5 simulation shows a good agreement with MODIS in the annual mean (ANN) SCF and the strong seasonality. The most persistent snow cover at the southern and western edges of the HTP and the relatively less persistent in the HTP interior are captured by the CAM5 model. The performance of the CAM5 has been improved, in comparison 
a) Muztagh Ata
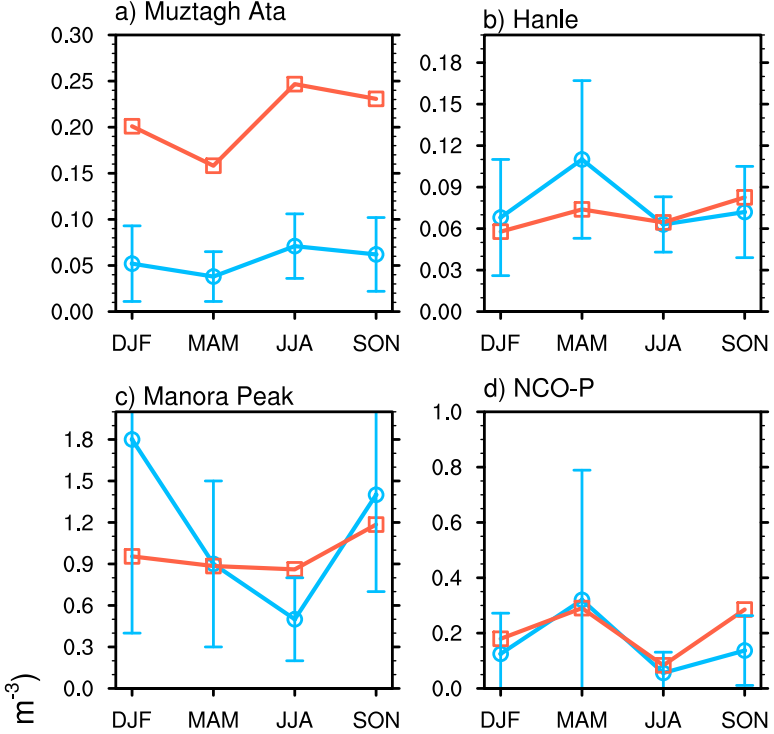

d) NCO-P
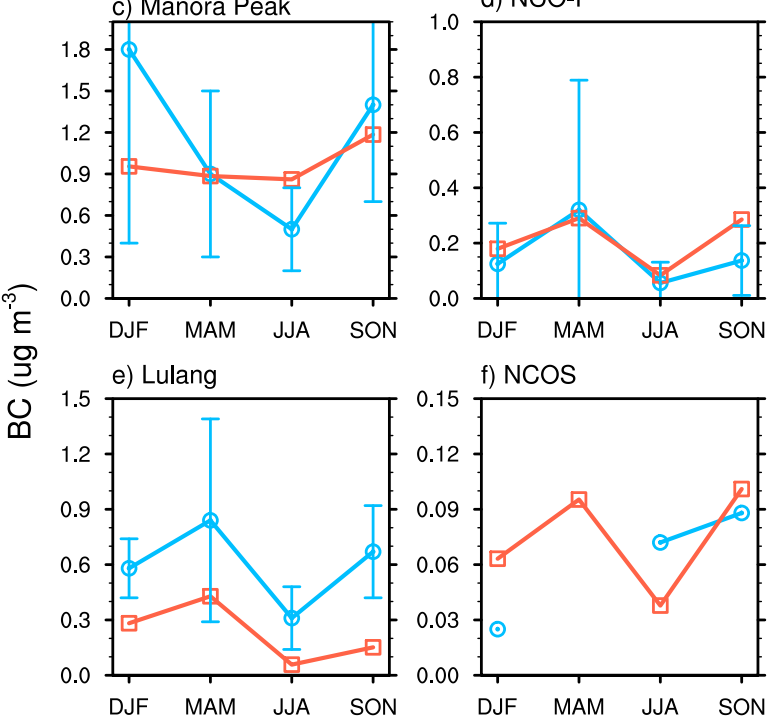

g) QSSGEE

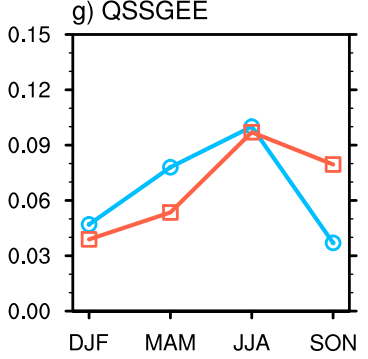

f) NCOS

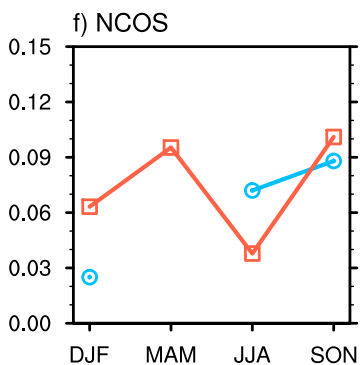

h) Sampling sites

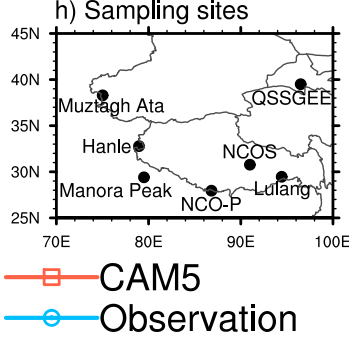

Figure 2. Seasonal mean surface $B C$ concentration $\left(\mu \mathrm{g} \mathrm{m}^{-3}\right)$ from observations (blue lines with error bars denoting SD) and CAM5 simulation (red lines) at the seven sampling sites listed in Table 1 and marked in the map of panel (h).

to its earlier version (CAM3) that remarkably overestimated the SCF especially over the HTP interior (Qian et al., 2011), although the CAM5 still significantly overestimates the SCF in the western plateau in DJF and MAM and underestimates it in JJA. The CAM3 model used by Qian et al. (2011) overestimates SCF by up to a factor of 2 during the cold season (November to April). The CAM3 spring (MAM) mean SCF is greater than $35 \%$, while the CAM5 spring mean (21\%) in the present study is in good agreement with the MODIS spring SCF $(18 \pm 5 \%)$.

Although we believe that the CAM5 SCF biases are qualitatively robust, it is worth noting that the MODIS products

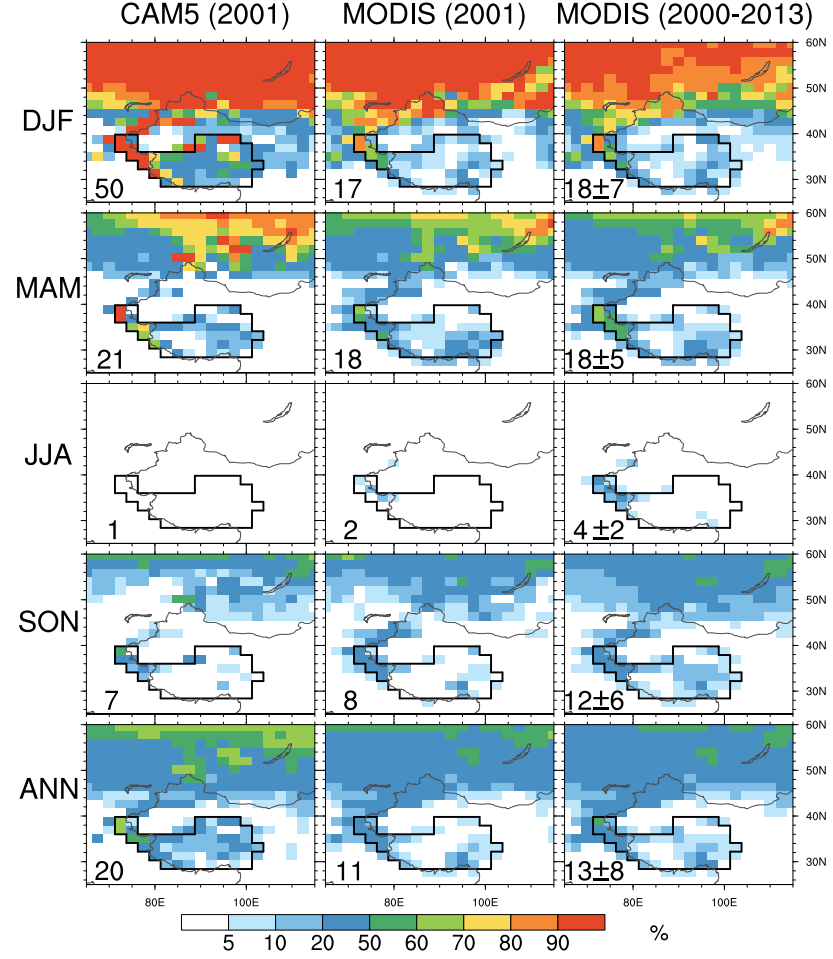

Figure 3. Seasonal and annual mean snow cover fraction from CAM5 simulation for year 2001 (left), and MODIS retrieval for 2001 (middle) and 2000-2013 (right). The summer (JJA) in 2001 for both CAM5 and MODIS only includes July and August due to missing MODIS data in June. The number in the lower-left corner of each panel is the corresponding spatial mean SCF for the HTP region (which is marked with a black outline), and for MODIS the standard deviation calculated from the MODIS multi-year means is also included.

have uncertainties as well. Pu et al. (2007) evaluated the MODIS SCF products over the HTP against ground-based snow observations and showed that total error in MODIS SCF products over the HTP is about $10 \%$. However, their analysis based on MODIS 8-day snow cover composite gave a significantly higher SCF (more than $10 \%$ ) than the one we show here using daily products, especially in winter and early spring. Interestingly, based on a different source of observation, Qin et al. (2006) found that snow covers about 59\% of the Tibetan Plateau in winter, which is comparable to the mean SCF (50\%) in our CAM5 simulation. Nonetheless, we keep this discrepancy in mind when interpreting the wintertime BC-in-snow radiative forcing that suffers the most from such potential SCF bias. 


\section{Modeled transport pathways and source attribution of $\mathrm{BC}$ in the HTP}

\subsection{Transport pathways}

The direct source-tagging method can clearly characterize the three-dimensional transport pathways of $\mathrm{BC}$ emitted from various source regions and sectors to the HTP receptor region. General circulation patterns over the HTP and surroundings are typically affected by midlatitude westerlies in the winter and Asian monsoon in the summer, including the South Asian summer monsoon and East Asian summer monsoon (Xu et al., 2009; Yao et al., 2012; Wu et al., 2012; also see Fig. S2).

Figure 4 illustrates circulation patterns over HTP and BC transport pathways from six major source regions to the HTP in the winter (DJF) and summer (JJA). (See similar plots in Figs. S3-S5 for other tagged source regions.) In the winter, the strong surface cooling over the HTP leads to subsidence/divergence and the formation of an enhanced local circulation cell, while in the summer air converges toward the HTP from the surroundings, particularly from South Asia, due to the ascending of strongly heated air over the HTP (e.g., Wu et al., 2012), as also indicated by the arrows in the vertical cross sections in Fig. 4. In the winter, the subtropical westerlies extend to about $10^{\circ} \mathrm{N}$ in middle/upper troposphere and $20^{\circ} \mathrm{N}$ near the surface, and the tropical easterlies are weak (see the white contours of latitude-height crosssection panels in Fig. 4). The circulation patterns near the HTP change dramatically during the summer monsoon season. The reversal of surface wind regime in the tropics (e.g., Arabian Sea, Bay of Bengal, and South China Sea) is characteristic of the Asian summer monsoon climate (see Fig. S2e, g). The subtropical westerlies recede to north of $30^{\circ} \mathrm{N}$ and the center of the westerly jet shifts to about $40^{\circ} \mathrm{N}$ in JJA (from about $30^{\circ} \mathrm{N}$ in DJF). The strong easterlies characterize the upper troposphere of tropical region (south of HTP), while the southwesterly flow prevails in the lower troposphere (white contours of latitude-height cross-section panels in Fig. 4). The prevailing winds during the transition seasons (MAM and SON) between DJF and JJA are still westerlies (Fig. S2b, d).

The circulation patterns determine the transport of $\mathrm{BC}$ around the HTP region. However, the variations in spatial distributions of $\mathrm{BC}$ emitted from the different source regions and in different seasons could be due to the differences in source location and strength, wet removal rate, and lifting. Note that although we combined $\mathrm{BC}$ emitted from BB and FF sections to characterize transport pathways in Fig. 4, only $\mathrm{BC}$ emissions from the $\mathrm{BB}$ sector have seasonal variations in the emission inventory we use.

The HTP region is surrounded by two major BC source regions, SAS and EAS (Fig. 1a), which potentially have great impact on BC in the HTP (e.g., Menon et al., 2010; Bond et al., 2007; Ohara et al., 2007; Xu et al., 2009; Kopacz et al., 2011; Lu et al., 2012). BC emissions from SAS are dominated by the BB sector, and by FF sector from EAS (Fig. 1b). As shown in Fig. 4, in the winter, a significant amount of BC from SAS can be transported to the eastern plateau by the strong westerlies under the dry winter monsoon conditions. During the South Asian summer monsoon BC from SAS is effectively removed by the local abundant precipitation, as indicated by the low lifetime in summer (Table S2), but can still affect large area in the southwest of the HTP. However, $\mathrm{BC}$ from EAS can be uplifted higher and transported more to the northeast plateau in the summer monsoon season than in the winter. Along the wintertime westerlies, $\mathrm{BC}$ from upwind source regions (e.g., EUR, NAF, SAF, MDE, and CAS; see Fig. S3) can easily move to the HTP, while the HTP local emissions are transported far away (Fig. 4). BC originating from the distant sources such as SAF and MDE reaches up high (to $300 \mathrm{hPa}$ ) in the HTP. In the summer, continental deep convection can loft BC into higher altitudes, where it can be transported to the HTP along the relatively weaker westerlies from upwind source regions (e.g., EUR, RBU, MDE, and CAS; see Figs. 4 and S3). However, BC from distant lowlatitude source regions such as SAF barely reaches the HTP region due to weak emissions but strong removal along the transport pathways to the HTP during the summer monsoon season.

\subsection{Seasonal variation in $\mathrm{BC}$ in the $\mathrm{HTP}$}

BC concentrations in the HTP have strong dependence on season and location. Figure 5 shows the annual mean and seasonal variations in $\mathrm{BC}$ column burden and deposition rate over the HTP and five subregions. The seasonal variation in the ratio of wet to total $\mathrm{BC}$ deposition is superimposed. The central plateau is the cleanest region during all seasons, compared to other subregions in the HTP (Fig. 5e). Both BC column burden and deposition rate from the BB sector peak in MAM over the HTP, mostly in the Himalayas and southeast plateau region. The FF BC burden in the HTP peaks in the summer mainly due to the seasonal maximum over the northwest and northeast plateaus. However, BC wet removal rate over the northwest plateau is at minimum in the summer, as opposed to the summer maximum in other subregions and the entire HTP region. For the Himalayas and the southeast and central plateau, the seasonal variation (i.e., maximum in MAM followed by a sharp decrease to JJA) in BB and FF column burden (Fig. 5c, d and e) is similar to the variation in observed surface concentrations at sites located in these subregions (Fig. 2b, d, e and f). In the Himalayas and the southeast plateau, the ratio of regional mean $\mathrm{BC}$ column burden to deposition rate (Fig. 5c and d), an indicator of removal timescale or lifetime, is the smallest (less than 1 day) during the Asian summer monsoon (JJA) due to the efficient wet scavenging of $\mathrm{BC}$ by abundant precipitation. In northwest and northeast plateau, the $\mathrm{BC}$ column burden increases from DJF to JJA and reaches the maximum in JJA, and then 


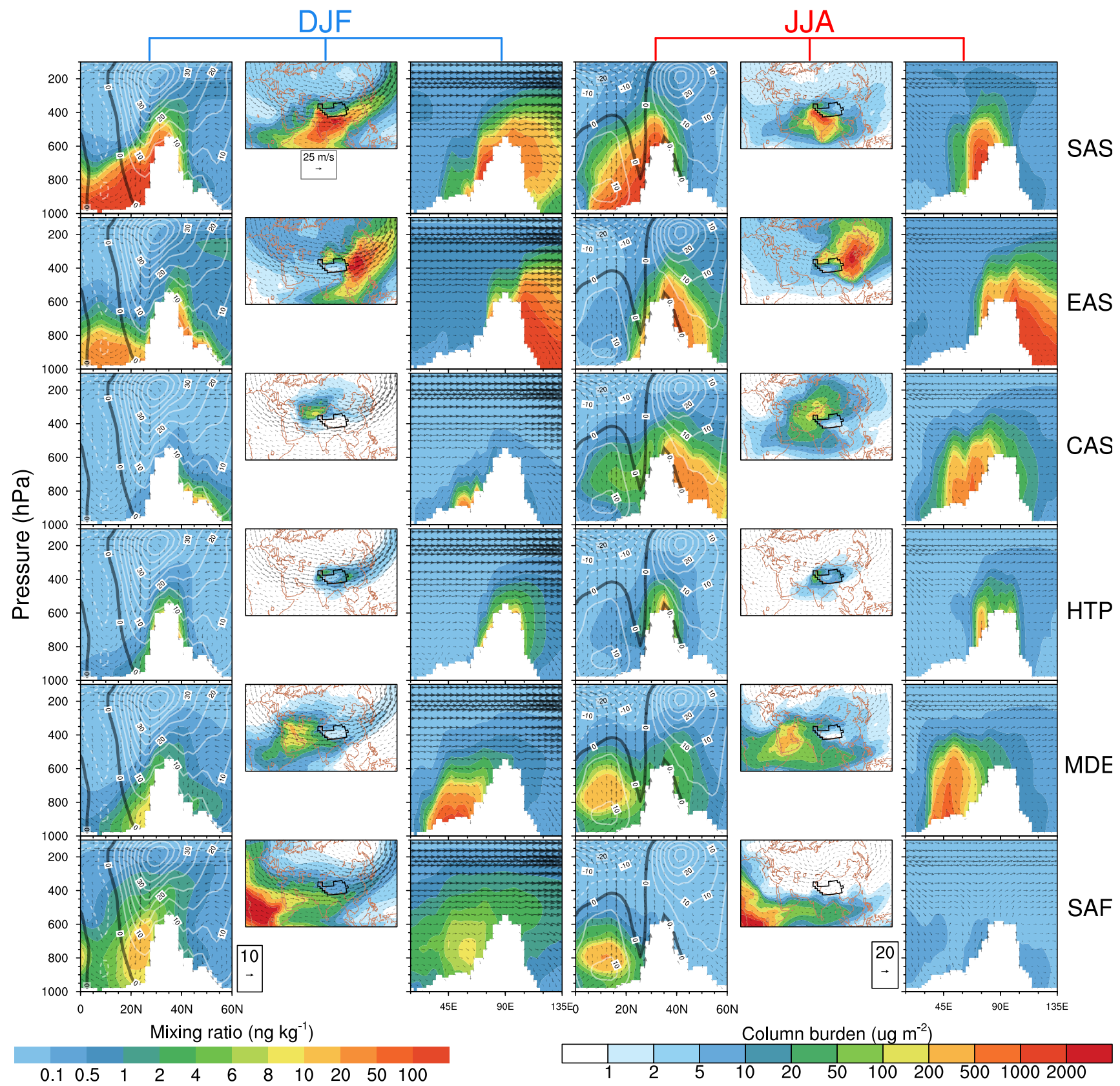

Figure 4. The first column shows the latitude-height distributions of DJF BC mass mixing ratios (in $\mathrm{ng} \mathrm{kg}^{-1}$, colors) averaged over 71.25$101.25^{\circ} \mathrm{E}$, originating from $\mathrm{BB}$ and FF sectors in the tagged source regions (corresponding to different rows); the white area denotes topography, and the superimposed white contours at intervals of $5 \mathrm{~m} \mathrm{~s}^{-1}$ represent the westerly (solid) and easterly (dashed) DJF mean zonal winds along the cross section with the thick solid black contour at $0 \mathrm{~m} \mathrm{~s}^{-1}$; the wind vectors (consisting of vertical velocity in units of $-10^{-4} \mathrm{hPa} \mathrm{s}^{-1}$ and meridional wind in $\mathrm{m} \mathrm{s}^{-1}$ ) are represented by arrows. Colors in the second column denote spatial distribution of the DJF mean BC column burden (in $\mu \mathrm{g} \mathrm{m}^{-2}$ ), originating from different source regions, and the arrows represent the DJF mean horizontal wind vectors at $500 \mathrm{hPa}$; the HTP is marked with a black outline. The third column is similar to the first column except that the quantities are on the longitude-height cross section averaged over $28-40^{\circ} \mathrm{N}$, and thus the horizontal component of the wind vectors is zonal wind ( $\mathrm{m} \mathrm{s}^{-1}$ ) instead. The fourth to sixth columns are the same as the first to third columns, respectively, but for JJA means instead. 


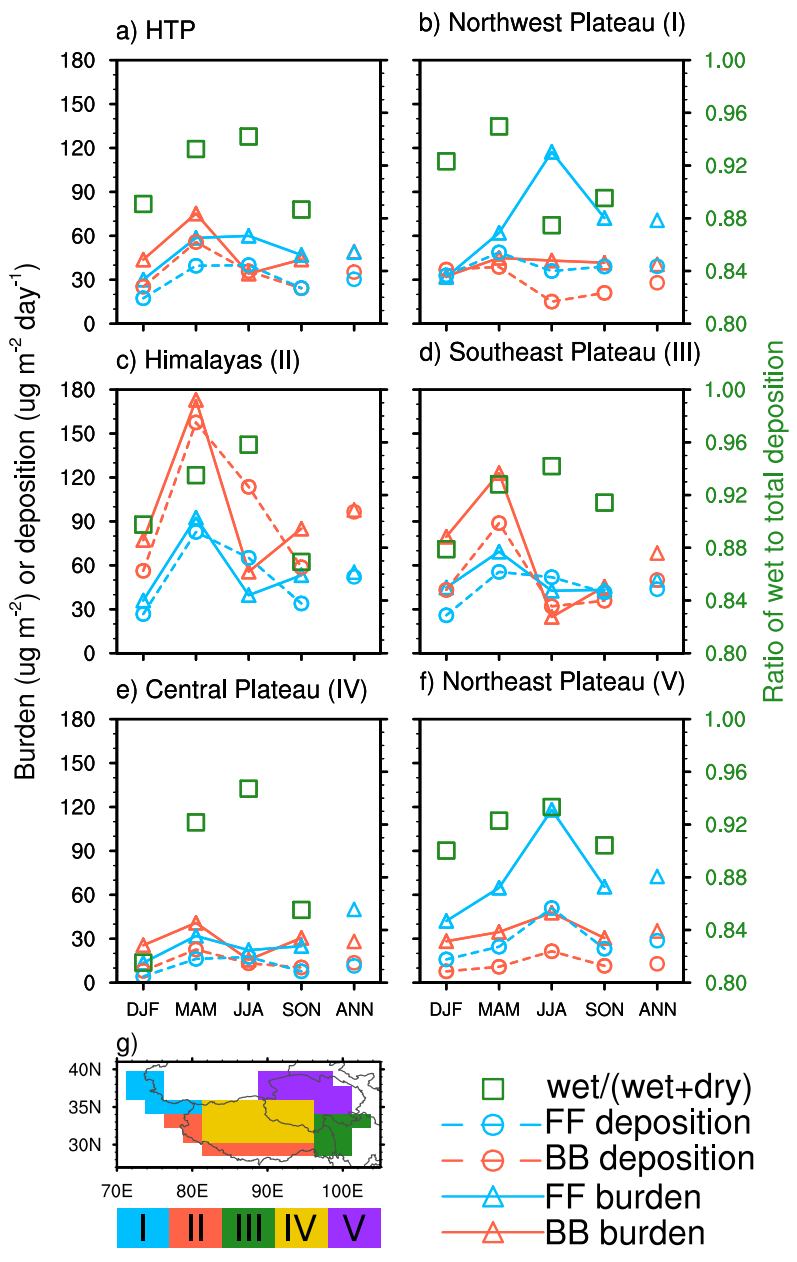

Figure 5. Seasonal and annual mean BC column burden (solid lines and open triangles, in $\mu \mathrm{g} \mathrm{m}^{-2}$ ) and deposition rate (dashed lines and open circles, in $\mu \mathrm{g} \mathrm{m}^{-2} \mathrm{day}^{-1}$ ) over (a) the HTP, (b) northwest plateau, (c) Himalayas, (d) southeast plateau, (e) central plateau and (f) northeast plateau, emitted from BB (red) and FF (blue) source sectors. The green squares denote the ratio of wet to total BC deposition (using $y$ axis on the right) in four seasons over each receptor region. The geographical locations of five subregions of HTP are indicated in panel $(\mathbf{g})$.

decreases in SON (Fig. 5b and f), partly due to the peak contribution of EAS and CAS emissions in JJA. This trend is also similar to that in the observed surface concentrations (Fig. 2a and g). The deposition rate follows the same seasonal variation in column burden over the northeast plateau, while the deposition has a minimum in JJA over the northwest plateau when the column burden is at maximum, likely due to the less efficient wet removal in this region (Fig. $5 \mathrm{~b}$ and f).

The annual mean BC column burden over the HTP has almost the same contributions from $\mathrm{BB}$ and $\mathrm{FF}$ emission origins, with BB dominating in DJF and MAM and FF in JJA. In the Himalayas, $\mathrm{BC}$ is predominantly from the $\mathrm{BB}$ sector for all seasons (Fig. 5c). In the southeast and central plateaus, the dominant source sector is BB in DJF and MAM, but FF dominates in JJA. The dominant source sector over the northwest and northeast plateaus is always FF, especially in the summer. We need to analyze the source-receptor relationships in order to quantify the roles of $\mathrm{BB}$ and $\mathrm{FF}$ emissions from the various source regions in determining BC over the HTP and the subregions.

\subsection{BC source-receptor relationships}

Previous studies (e.g., Xu et al., 2009; Kopacz et al., 2011) have shown that $\mathrm{BC}$ and its source-receptor relationships vary significantly with season and location in the HTP. We intend to quantify source contributions to BC at different locations of the HTP and in different seasons. Our analysis also shows that the relative contributions to $\mathrm{BC}$ from different source regions and sectors depend on season and location in the HTP. As shown in Fig. 6, the largest contribution to the annual mean $\mathrm{BC}$ burden and surface deposition for the entire HTP region is from BB emissions from SAS, followed by FF emissions from SAS and then the FF from EAS. The same roles hold for all the seasonal means except for the summer (JJA), when the EAS FF becomes more important for BC column burden in the HTP and, to a lesser extent, for deposition.

The SAS emissions account for $50 \%$ of the annual mean burden over the HTP, including $33 \%$ from BB and $17 \%$ from FF. The other $50 \%$ is mostly from the EAS $(5 \%$ BB and $14 \% \mathrm{FF})$, HTP (6\% BB and $6 \% \mathrm{FF})$, CAS FF (4\%), MDE FF $(4 \%)$, and SAF BB (3\%). The source attribution for annual mean BC deposition for the entire HTP is similar, but SAS contributes even more to BC deposition than to the column burden. Although RBU has a lower contribution to the annual mean BC in the HTP than the six regions shown in Fig. 6, its contribution to the JJA mean, especially at some locations, is quite substantial (included in the black bar) and even more important than some of the six regions in Fig. 6, as discussed in detail below.

BC annual mean burden over the HTP has nearly equal contributions from BB and FF emissions. However, the contribution by BB emissions, mainly from SAS, is larger than from the FF sector in DJF and MAM. In the summer (JJA), the largest contribution (about $29 \%$ ) to HTP BC is from EAS FF emissions. This is partly due to the change in circulation patterns (Fig. 4) and effective wet removal of SAS BB emissions. Note that EAS FF emissions are much larger than FF emissions from any other of the source regions, and are more than twice the EAS BB emissions.

For $\mathrm{BC}$ in the five finer receptor regions of interest (as defined in Fig. 5g), SAS BB and FF have the largest contribution to $\mathrm{BC}$ in the Himalayas and central plateau, while EAS FF and BB contribute the most to the northeast plateau in all seasons and southeast plateau in the summer. Central Asia and Middle East FF emissions have relatively more im- 

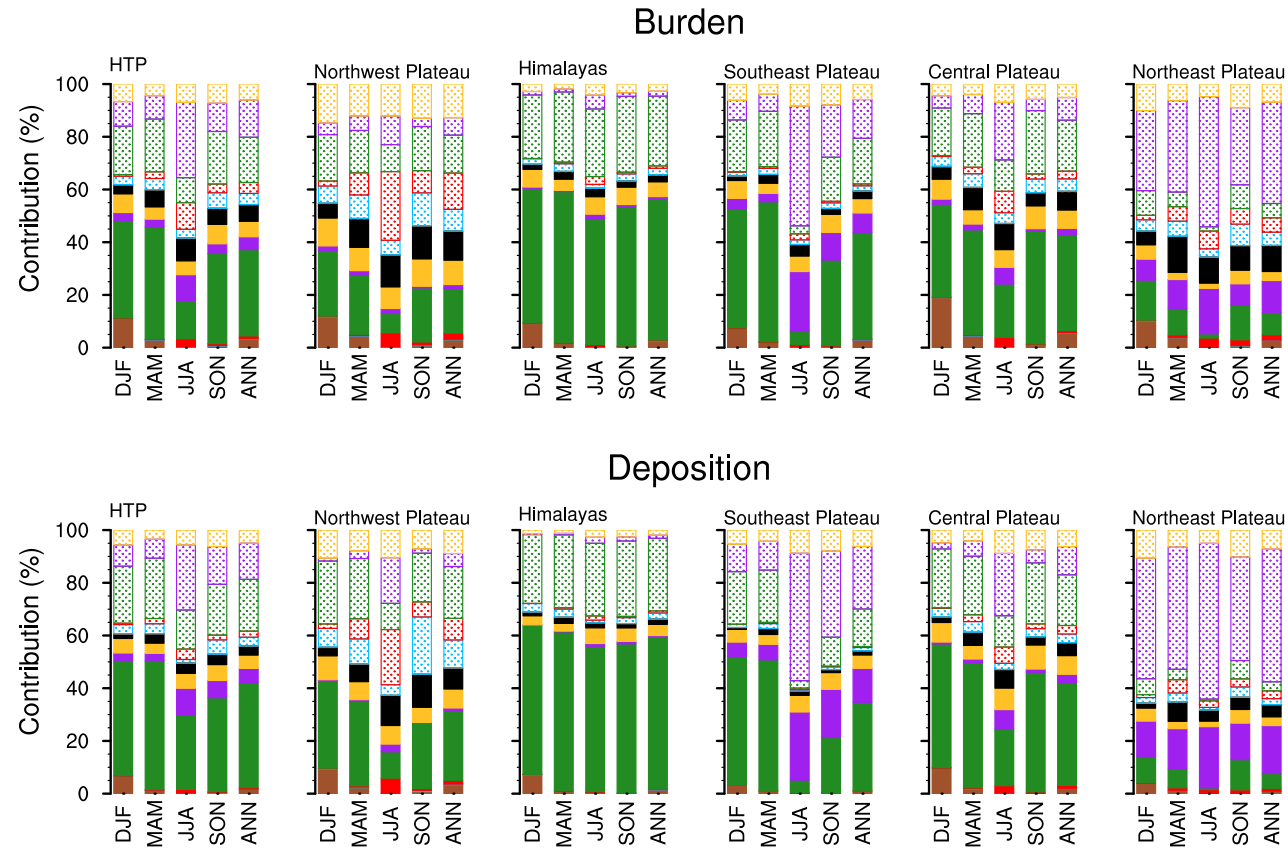

Deposition
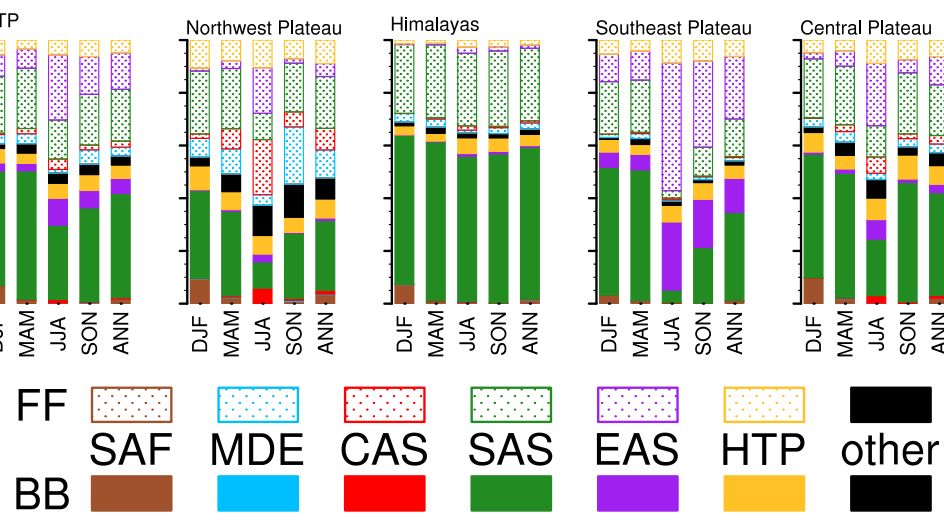

Figure 6. Fractional contributions (measured by the lengths of color bars) to seasonal and annual mean BC column burden (top six panels) and deposition (bottom six panels) over the HTP, northwest plateau, Himalayas, southeast plateau, central plateau, and northeast plateau, originating from six major tagged source regions (indicated by colors) for BB (solid bar) and FF (dotted bar) emissions. The black bar in each column represents the contribution from all of the other tagged source regions and sectors combined.

portant contribution to $\mathrm{BC}$ reaching the northwest plateau, especially in the summer.

For the northwest plateau, the prevailing winds in this subregion are westerly throughout the year (Fig. S2; Cao et al., 2009; Xu et al., 2009), so the important source regions should be located at the west of the HTP (e.g., MDE, EUR, and parts of SAS and RBU in Fig. 1a). As shown in Fig. 6, SAS emissions are still the dominant source for the annual $\mathrm{BC}$ burden in this subregion (17\% from $\mathrm{BB}$ and $14 \%$ from $\mathrm{FF}$ ), followed by HTP local emissions (9\% from BB and $13 \%$ from $\mathrm{FF}), \mathrm{CAS}(2 \%$ from BB and $14 \%$ from FF), MDE FF ( $8 \%$ ), and EAS FF (7\%). BC emissions from SAS are the dominant source in DJF, MAM, and SON. CAS becomes the dominant source region ( $5 \%$ from $\mathrm{BB}$ and $26 \%$ from $\mathrm{FF}$ ) in JJA, even though CAS is not a significant emission source region on a global basis (Fig. 1b). BC emitted from MDE is predominantly in the FF sector throughout the year. Emissions from the rest of the tagged sources (in addition to the six sources listed; black bar in Fig. 6) become more significant in this subregion, mostly from EUR and RBU through long-range transport (Fig. S3). The source attribution for BC deposition in this subregion is similar to that of the column burden, but BC emitted from SAS and MDE appears to be more efficient in deposition, except for the JJA season, when BC from EAS contributes more to deposition than to column burden.

The Himalayas subregion located along the southern edge of the HTP is in close proximity to the SAS. Thus emissions from SAS are absolutely the dominant source for BC in the Himalayas throughout the year. This subregion receives more $\mathrm{BC}$ from the BB sector than FF because $\mathrm{BC}$ emissions in SAS are mainly in the BB sector, especially in the MAM season (Figs. 1b and S6). For the annual mean burden, BC from SAS contributes $81 \%$ (54\% from BB and $27 \%$ from FF), followed by HTP local emissions (6\% from BB and $3 \%$ from FF). It is worth noting that SAF BB emissions contribute about $10 \%$ to burden in DJF through long-range transport. BC deposition in this subregion also predominantly originates from SAS, which is consistent with previous studies by Ming et al. (2008) and Kopacz et al. (2011).

For the southeast plateau (Fig. 6), the BC source contribution profile is similar to that of Himalayas during DJF and MAM season, in which SAS is still the dominant source, especially in MAM (74\% contribution to column burden, including $53 \%$ from BB and $21 \%$ from FF), although the contribution from EAS is larger here than for the Himalayas. As also pointed by Ramanathan et al. (2007), BC over the SAS can be transported to the southeast plateau by the southern 
branch of the westerlies during the winter and spring. However, the BC source contribution profile changes dramatically during the summer, when emissions in EAS become the dominant source to this subregion $(68 \%$ to column burden, including $23 \%$ from BB and $45 \%$ from FF). Kopacz et al. (2011) also found that the BC from southeastern China is the dominant contributor to the southeast plateau in July. For the annual mean burden in this subregion, SAS is still the dominant contributor ( $40 \%$ from BB and $17 \%$ from $\mathrm{FF}$ ), followed by EAS ( $8 \%$ from BB and $15 \%$ from FF), and HTP ( $6 \%$ from $\mathrm{BB}$ and $6 \%$ from $\mathrm{FF}$ ). $\mathrm{BC}$ originating from $\mathrm{EAS}$ contributes more to deposition than to burden in this subregion.

For the central plateau (Fig. 6), source attribution profiles for annual and seasonal BC are very similar to those of the entire HTP region, with SAS being the dominant source region throughout the year, except that EAS has comparable contributions in JJA. Ming et al. (2010) pointed out that pollutants from the Indo-Gangetic Basin could be transported to the central plateau by both the summer monsoon and the westerlies. Xia et al. (2011) also found that the substantial regional atmospheric brown haze from the nearby regions of SAS is the main source for the background aerosols in the central plateau based on sun photometer and satellite observations.

Compared to the other subregions, the northeast plateau receives the largest contribution of $\mathrm{BC}$ from EAS throughout the year (50\% to annual mean burden, including $12 \%$ from BB and $38 \%$ from FF; see Fig. 6), especially in JJA (17\% from $\mathrm{BB}$ and $49 \%$ from FF). The EAS FF sector contribution and the magnitude of burden (Fig. 5f) over the northeast plateau have strong seasonal variations, mostly due to variations in meteorology, because the FF emissions in our simulation do not vary seasonally. Kopacz et al. (2011) indicate that the primary contribution to $\mathrm{BC}$ over the northeast plateau is from western China during January and April (transported by midtropospheric westerlies), and from central-eastern China during July and October (transported by boundarylayer flow). Other main contributions to BC burden over the northeast plateau include $13 \%$ from SAS and 10\% from HTP local emissions. Similar to the northwest plateau, some other upwind source regions (e.g., CAS, MDE, RBU, and EUR; see Figs. 4 and S3) have a significant contribution to the northeast subregion as well.

\subsection{Seasonal variation in HTP BC sensitivity}

Following Wang et al. (2014), we defined the "efficiency" metric in Sect. 2.2 to quantify the sensitivity of BC response to absolute change (e.g., per unit perturbation) of emissions in different source regions. This metric has the value of 1 if the entire globe is treated as a single source region, so we may assume the global mean efficiency of 1 as a reference to measure the sensitivity to perturbation from different source regions/sectors.
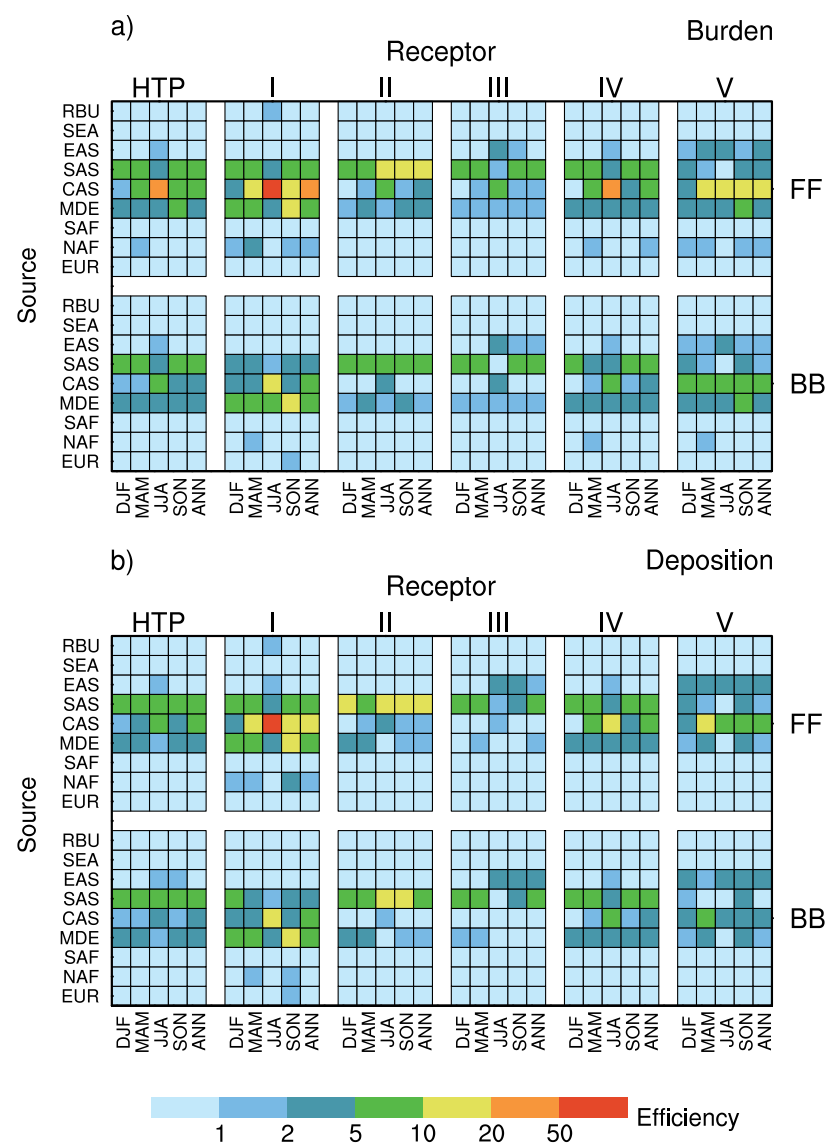

Figure 7. Efficiency of FF (top) and BB (bottom) emissions from 9 source regions (on the $y$ axis) in changing seasonal and annual mean (a) BC column burden and (b) deposition over the HTP and each of the five subregions: northwest plateau (I), Himalayas (II), southeast plateau (III), central plateau (IV), and northeast plateau (V).

Figure 7 shows efficiencies of tagged sources in affecting the BC seasonal and annual mean column burden and deposition in the HTP and five subregions (as defined in Fig. 5g). $\mathrm{BC}$ in the same receptor regions is generally most sensitive to change in local emissions, regardless of seasons, emission sectors, and locations of receptor regions. Among all the source regions, although the HTP local $(\mathrm{FF}+\mathrm{BB})$ emissions only contribute about $10 \%$, BC in the HTP is extremely sensitive to changes in the emissions within HTP (not shown in the figure), mainly because the emission rate is very low. In addition to the local emissions, BC in the HTP is also sensitive to emissions in neighboring source regions (e.g., SAS and CAS) and emissions from distant sources such as MDE. The SAS has a large contribution to BC burden and deposition over the HTP, as well as most of the subregions except for the northeast plateau (receptor V); the efficiencies for SAS emissions are also high for almost all of the subregions especially the Himalayas (receptor II). BC in the northeast plateau (receptor V) is quite sensitive to EAS emissions 
in all seasons, while $\mathrm{BC}$ in the southeast plateau is sensitive to EAS emissions in JJA and SON. Although BC emissions from MDE and CAS are weak (Fig. 1b) and their contributions to the HTP are relatively low, their efficiencies are high. $\mathrm{BC}$ over the northwest plateau (receptor I) and central plateau (receptor IV) is extremely sensitive to emissions from CAS in JJA. These source-receptor relationships of sensitivity will provide useful information for policymakers to improve the effective mitigation road map in order to potentially slow down the glacier retreat in the HTP region.

\section{Radiative forcing}

The BC-in-snow effect can be quantified using the online calculation of radiative forcing in the SNICAR (Snow, Ice, and Aerosol Radiative) model (Flanner et al., 2007) coupled to CAM5, and then compared to airborne $\mathrm{BC}$ radiative forcing. Figure 8 shows seasonal and annual mean BC all-sky shortwave direct radiative forcing (DRF) at the surface (dimming) and the top of the atmosphere (TOA), and the BC-in-snow radiative forcing (darkening) averaged over the entire HTP and the five subregions (as defined in Fig. 5g). Note that the BC-in-snow forcing is averaged over all model grids in the area (i.e., zero enters the calculation for any grid when snow is not present). The radiative forcing of $\mathrm{BC}$ (and dust) in snow is small in JJA and SON due to a lack of snow cover (Fig. 3). The forcing maximum occurs during the spring melt (MAM), when the insolation is rather intense and BC accumulates at the surface of the snowpack as the snow melts (Conway et al., 1996; Flanner et al., 2007, 2009), and when the snow-albedo feedback is strongest (Hall and Qu, 2006). This strong seasonal variation also explains why the coefficient of variation (i.e., the ratio of the SD to the mean) is greater than 1 for the annual mean BC-in-snow forcing over the entire HTP and all subregions. The seasonal variations in airborne BC DRF at the TOA and surface are consistent with that of the BC column burden (Fig. 5). For the entire HTP (Fig. 8a1), the annual mean surface radiative forcing due to $\mathrm{BC}$ in snow $\left(0.42 \mathrm{~W} \mathrm{~m}^{-2}\right)$ exceeds the $\mathrm{BC}$ dimming effect at the surface $\left(-0.3 \mathrm{~W} \mathrm{~m}^{-2}\right)$. The annual mean $\mathrm{BC}$-in-snow forcing is even higher over the northwest plateau (Fig. 8b1) and Himalayas (Fig. 8c1), and far exceeds the other forcings in the same subregions, although the BC-in-snow effect may be overestimated due to the potential positive bias in snow cover fraction in our simulation (Fig. 3). The annual mean $\mathrm{BC}$ surface dimming exceeds the BC-in-snow effect in the southeast (Fig. 8d1), central (Fig. 8e1), and northeast plateau (Fig. 8f1). The minima of all BC-related forcings appear in the central plateau, where the $\mathrm{BC}$ burden and deposition are the lowest among all the subregions (Fig. 5), and the SCF is very small (Fig. 3).

We have also calculated an approximate source attribution for the BC-in-snow radiative forcing over the HTP and its subregions, using the tagged-source $\mathrm{BC}$ deposition, which is

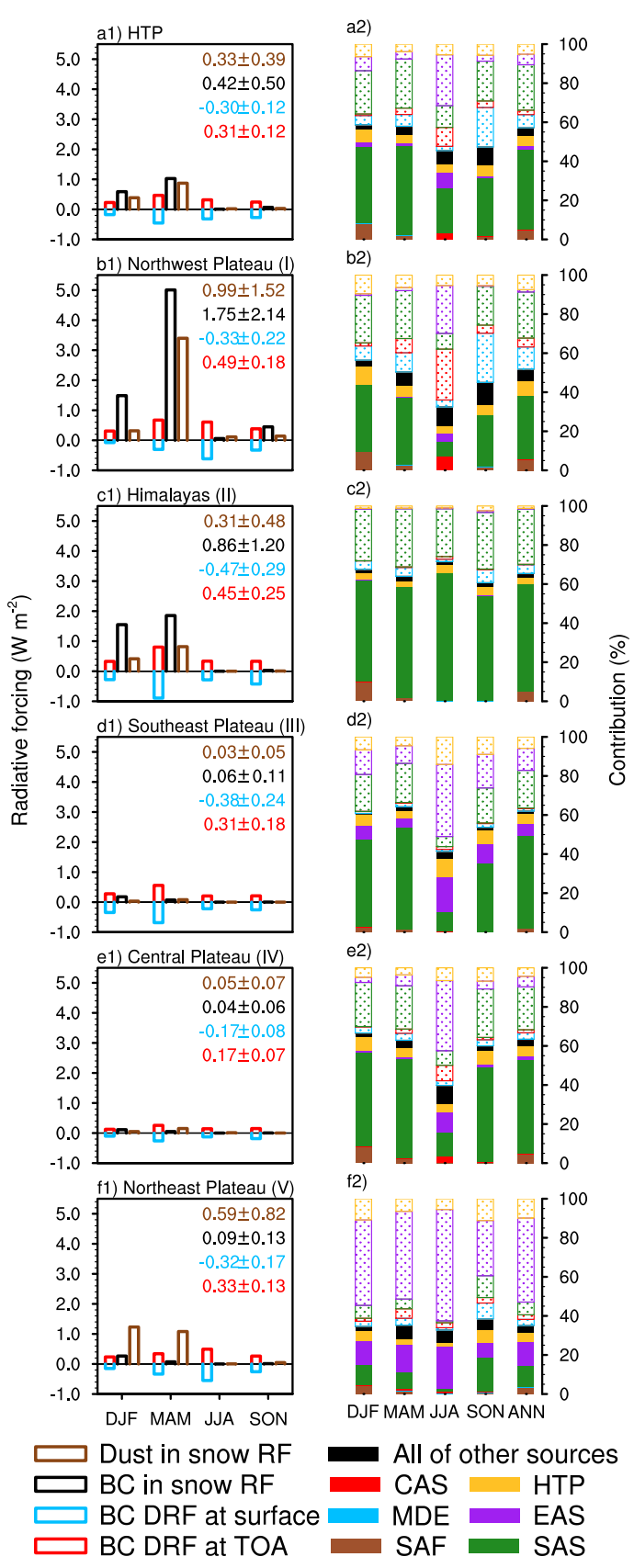

Figure 8. Seasonal mean radiative forcing (left column) induced by the various $\mathrm{BC}$ effects (indicated by the color legend at the bottom) and dust-in-snow effect over (a1) the HTP, (b1) northwest plateau, (c1) Himalayas, (d1) southeast plateau, (e1) central plateau, and (f1) northeast plateau. The corresponding annual mean forcings and one SD (for 12 monthly means) are shown in numbers on the topright corner of each panel. The right column (a2-f2) panels represent source contribution to surface $\mathrm{BC}$-in-snow radiative forcing over the corresponding receptors from tagged source regions (colors) and sectors (solid pattern bar and dotted pattern bar for BB and FF, respectively). The black bar in each column represents the contribution from all of the other tagged source regions and sectors. 
simply assumed to be linearly proportional to BC-in-snow radiative forcing. The SCF is taken into account in the calculation (i.e., the deposition at each model grid is multiplied by SCF when calculating the area-average deposition). Overall, despite small quantitative differences, the source contributions to BC-in-snow forcing are similar to those for BC deposition (Fig. 6). The SAS BB emissions contribute the most to annual mean forcing over the HTP and subregions except for the northeast plateau, for which the contribution is mostly by EAS FF emissions. During the winter and spring seasons over the northwest plateau and Himalayas, when and where the forcing is the largest, SAS (especially the BB sector) is the major contributor.

Dust is a major contributor to the total aerosol burden over the HTP (e.g., Zhang et al., 2001). Although we do not focus on other snow impurities such as mineral dust, it is worth noting that dust-in-snow radiative forcing has been considered in our model simulation, and it could be an important forcing agent. We also plotted dust-in-snow forcing over the HTP and subregions in Fig. 8 (along with the BC-induced forcings). The annual mean dust-in-snow forcing $\left(0.33 \mathrm{~W} \mathrm{~m}^{-2}\right)$ is comparable to all of the other forcings over the HTP, especially in the springtime, when dust outbreaks occur and can be transported to the HTP from the surrounding sources such as the Taklimakan and Gobi deserts (Liu et al., 2008). The annual mean dust-in-snow forcing is as large as 0.99 and $0.59 \mathrm{~W} \mathrm{~m}^{-2}$ in the northwest and northeast plateau, respectively (Fig. 8b1 and f1), which is in close proximity to the Taklimakan Desert (Huang et al., 2007; Chen et al., 2013), but negligibly small in the southeast plateau and central plateau. In the winter, the dominant dust-in-snow effect over the northeast plateau is consistent with the recent observations. Huang et al. (2011), X. Wang et al. (2013) and Zhang et al. (2013) found that insoluble light-absorbing particles in snow are dominated by local soil and desert dust in the Qilian Mountains (northeast plateau).

Both snow cover fraction (SCF) and mass concentration of snow impurities affect the calculation of radiative forcing in snow. We have evaluated the model estimation of SCF in different seasons (Fig. 3). We have also compared BC concentration and deposition flux from our model results to a recent modeling study by Ménégoz et al. (2014) and to observations in the HTP (Ginot et al., 2014) (Table S3). Bond et al. (2013) pointed out that observations of BC in snow pits or ice cores mostly involve snow/ice samples obtained in the summer and early fall, when almost all grid boxes the sample sites located in are snow free in the HTP. They also indicated that the CAM3 global climate model (Flanner et al., 2009) may be overestimating snow BC concentrations in the HTP, especially in the spring. Our comparison shows that despite a smaller bias than in Ménégoz et al. (2014) the CAM5 model still largely overestimates BC concentrations in snow but underestimates dust concentrations in snow over the HTP. Ménégoz et al. (2014) provided a few possible reasons for the differences between model simulations and observations.
Factors such as measurement uncertainties (due to sample treatment and analysis methodology), temporal (interannual and seasonal), and spatial variations in BC deposition, and vertical variations in $\mathrm{BC}$ in snowpack, can strongly affect the accuracy and representativeness of BC-in-snow measurements for the purpose of evaluating global models. Ming et al. (2013) and Qian et al. (2015) pointed out that BC concentrations in snow and ice samples over the HTP tend to decrease with increasing glacier elevations, while global models with coarse grid resolution cannot accurately represent elevation of sampling sites. Often times the difference is significant. Nonetheless, it is likely that positive biases exist in the modeled concentration and radiative forcing of $\mathrm{BC}$ and dust in snow.

\section{Summary and conclusions}

In this study, we employed the CAM5 model with a newly developed source-tagging technique, nudged towards the MERRA meteorological reanalysis, to characterize the fate of BC particles emitted from various geographical regions and sectors to the HTP region. In addition, we compare the radiative forcing induced by $\mathrm{BC}$ in the atmosphere and in snow over the HTP, as well as forcing induced by dust in snow. Although there are biases in the simulated BC, partly due to the inherent difficulty for coarse-resolution global models to accurately represent transport and wet deposition in this topographically complex region, the CAM5 model simulation shows a reasonable agreement in the seasonal variation in the near-surface airborne $\mathrm{BC}$ concentrations with observations over the HTP and surrounding regions. This provides us the confidence to use this modeling framework to characterize BC source-receptor relationships in the HTP. Using very different approaches, Kopacz et al. (2011), Lu et al. (2012), and the present study all show that South Asia and East Asia are the main source regions for BC transported to the HTP, while the magnitude of contributions from each of the source regions varies with season and receptor location. Although all of the three studies can provide quantitative source attributions, a quantitative intercomparison of the findings is quite difficult, given the differences in the definition of geographical source and receptor regions, emission inventories, time periods for model simulation, and analysis methods. Nevertheless, in addition to quantifying the contributions of source regions, our direct source-tagging approach allows us to further break down regional contributions by sectors (i.e., fossil fuel vs. biomass and biofuel) and to characterize the transport pathways of individual regional/sectoral emissions.

The explicit source-tagging technique enables the characterization of three-dimensional transport pathways of $\mathrm{BC}$ to the HTP from different geographical regions and source sectors, which also depends on seasons and the location of the receptor in the HTP. With the IPCC AR5 present-day emis- 
sion inventories, the annual mean BC column burden and surface deposition in the entire HTP region is contributed the most by biomass and biofuel (BB) emissions from South Asia (SAS) (33 and 40\%, respectively), followed by fossil fuel (FF) emissions from SAS (17 and $20 \%$, respectively) and then the FF from East Asia (EAS) (14 and 14\%, respectively). The same roles hold for all the seasonal means except for the summer, when the EAS FF becomes more important. Although BC emissions from the entire EAS source region are much stronger than those from SAS, the concentrated FF $\mathrm{BC}$ emissions in central-eastern China are only transported towards the HTP during the East Asian summer monsoon. Thus seasonal prevailing winds are important in determining the seasonal variations in $\mathrm{BC}$ transport and source-receptor relationships.

Both the annual and seasonal mean BC properties and their source-receptor relationships vary significantly with location in the HTP. For the multiple finer receptor regions of interest, SAS BB and FF have the largest impact on BC in the Himalayas and central plateau, while EAS FF and BB contribute the most to northeast plateau in all seasons and southeast plateau in the summer. The Central Asia (CAS) and Middle East (MDE) FF emissions make important contributions to $\mathrm{BC}$ over the northwest plateau, especially from CAS in JJA.

The HTP BC is most sensitive by far to per unit changes in the local emissions, although they only contribute about $10 \%$ to the $\mathrm{BC}$ burden in the HTP. The SAS region makes large contributions to BC burden and deposition over the HTP, and the BC sensitivities to SAS emissions are also high for almost all of the subregions of HTP, especially the Himalayas. $\mathrm{BC}$ over the northeast plateau is quite sensitive to EAS emissions in all seasons, and southeast plateau BC is also sensitive to EAS emissions in JJA. Although BC emissions from MDE and CAS are weak and their contributions to the HTP overall are low, their efficiencies are quite high. BC over the northwest and central plateau is extremely sensitive to emissions from CAS in JJA. These source-receptor relationships and sensitivities can be useful to policymakers for improving the effective mitigation road map in order to potentially slow down the glacier retreat in the HTP region.

The impact of $\mathrm{BC}$ on snow and glacier melting can be characterized by the magnitude of radiative forcing. Our calculations show that the annual mean $\mathrm{BC}$-in-snow radiative forcing $\left(0.42 \mathrm{~W} \mathrm{~m}^{-2}\right)$ outweighs the $\mathrm{BC}$ dimming effect $\left(-0.3 \mathrm{~W} \mathrm{~m}^{-2}\right)$ at the surface over the HTP. In the five subregions, the annual mean $\mathrm{BC}$-in-snow forcing ranges from $0.04 \mathrm{~W} \mathrm{~m}^{-2}$ in the central plateau to $1.75 \mathrm{~W} \mathrm{~m}^{-2}$ in the northwest plateau. We also showed that the annual mean dust-in-snow radiative forcing over the HTP can be quite significant $\left(0.33 \mathrm{~W} \mathrm{~m}^{-2}\right.$ for the entire HTP, and $0.99 \mathrm{~W} \mathrm{~m}^{-2}$ for the northwest plateau). More importantly, both BC- and dustin-snow forcing peaks in the spring melting season, when the area-average forcing reaches 1.03 and $0.87 \mathrm{~W} \mathrm{~m}^{-2}$, respectively, over the entire HTP, and their combined forcing is more than $8 \mathrm{~W} \mathrm{~m}^{-2}$ over the northwest plateau. Such a large forcing is sufficient to cause earlier snow melting and contribute to the acceleration of glacier retreat, although the model is likely to overestimate BC-in-snow forcing due to the possible positive bias of snow cover fraction in the winter and early spring. According to our estimates of the source attribution, the biomass burning and biofuel emissions in South Asia contribute the most to annual mean forcing over the HTP and its subregions except for the northeast plateau, where the largest contribution is from East Asia fossil fuel emissions. During the winter and spring seasons over the northwest plateau and Himalayas, when and where the forcing is the largest, South Asia (especially the biomass burning and biofuel sector) is the major contributor.

\section{The Supplement related to this article is available online at doi:10.5194/acp-15-6205-2015-supplement.}

Acknowledgements. This research is based on work supported by the U.S. Department of Energy (DOE), Office of Science, Biological and Environmental Research as part of the Earth System Modeling Program. The Pacific Northwest National Laboratory (PNNL) is operated for DOE by Battelle Memorial Institute under contract DE-AC05-76RLO1830. The CESM project is supported by the National Science Foundation and the DOE Office of Science. R. Zhang acknowledges support from the China Scholarship Fund. J. Huang and Q. Fu acknowledge support from the National Basic Research Program of China (2012CB955303), NSFC grant 41275070, and the China 111 project (no. B13045). Computational resources were provided by the National Energy Research Scientific Computing Center (NERSC), a national scientific user facility located at Lawrence Berkeley National Laboratory in Berkeley, California. NERSC is the flagship scientific computing facility for the Office of Science of DOE.

Edited by: X. Xu

\section{References}

Babu, S. S., Chaubey, J. P., Moorthy, K. K., Gogoi, M. M., Kompalli, S. K., Sreekanth, V., Bagare, S. P., Bhatt, B. C., Gaur, V. K., Prabhu, T. P., and Singh, N. S.: High altitude ( $4520 \mathrm{~m}$ a.m.s.l.) measurements of black carbon aerosols over western transHimalayas: Seasonal heterogeneity and source apportionment, J. Geophys. Res., 116, D24201, doi:10.1029/2011JD016722, 2011.

Barnett, T. P., Adam, J. C., and Lettenmaier, D. P.: Potential impacts of a warming climate on water availability in snow-dominated regions, Nature, 438, 303-309, doi:10.1038/Nature04141, 2005.

Bolch, T., Kulkarni, A., Kääb, A., Huggel, C., Paul, F., Cogley, J., Frey, H., Kargel, J., Fujita, K., Scheel, M., Bajracharya, S., and Stoffel, M.: The state and fate of Himalayan Glaciers, Science, 336, 310-314, doi:0.1126/science.1215828, 2012. 
Bonasoni, P., Laj, P., Marinoni, A., Sprenger, M., Angelini, F., Arduini, J., Bonafè, U., Calzolari, F., Colombo, T., Decesari, S., Di Biagio, C., di Sarra, A. G., Evangelisti, F., Duchi, R., Facchini, MC., Fuzzi, S., Gobbi, G. P., Maione, M., Panday, A., Roccato, F., Sellegri, K., Venzac, H., Verza, G. P., Villani, P., Vuillermoz, E., and Cristofanelli, P.: Atmospheric Brown Clouds in the Himalayas: first two years of continuous observations at the Nepal Climate Observatory-Pyramid (5079 m), Atmos. Chem. Phys., 10, 7515-7531, doi:10.5194/acp-10-7515-2010, 2010.

Bond, T. C., Bhardwaj, E., Dong, R., Jogani, R., Jung, S., Roden, C., Streets, D. G., and Trautmann, N. M.: Historical emissions of black and organic carbon aerosol from energy-related combustion, 1850-2000, Global Biogeochem. Cy., 21, GB2018, doi:10.1029/2006GB002840, 2007.

Bond, T. C., Doherty, S. J., Fahey, D. W., Forster, P. M., Berntsen, T., DeAngelo, B. J., Flanner, M. G., Ghan, S., Kärcher, B., Koch, D., Kinne, S., Kondo, Y., Quinn, P. K., Sarofim, M. C., Schultz, M. G., Schulz, M., Venkataraman, C., Zhang, H., Zhang, S., Bellouin, N., Guttikunda, S. K., Hopke, P. K., Jacobson, M. Z., Kaiser, J. W., Klimont, Z., Lohmann, U., Schwarz, J. P., Shindell, D., Storelvmo, T., Warren, S. G., and Zender, C. S.: Bounding the role of black carbon in the climate system: A scientific assessment, J. Geophys. Res.-Atmos., 118, 5380-5552, doi:10.1002/jgrd.50171, 2013.

Cao, J. J., Xu, B. Q., He, J. Q., Liu, X. Q., Han, Y. M., Wang, G. H., and Zhu, C. S.: Concentrations, seasonal variations, and transport of carbonaceous aerosol at a remote Mountainous region in western China, Atmos. Environ., 43, 4444-4452, doi:10.1016/j.atmosenv.2009.06.023, 2009.

Chen, S., Huang, J., Zhao, C., Qian, Y., Leung, L. R., and Yang, B.: Modeling the Transport and Radiative Forcing of Taklimakan Dust over the Tibetan Plateau in Summer, J. Geophys. Res., 118, 797-812, doi:10.1002/jgrd.50122, 2013.

Conway, H., Gades, A., and Raymond, C. F.: Albedo of dirty snow during conditions of melt, Water Resour. Res., 32, 1713-1718, doi:10.1029/96WR00712, 1996.

Dentener, F., Kinne, S., Bond, T., Boucher, O., Cofala, J., Generoso, S., Ginoux, P., Gong, S., Hoelzemann, J. J., Ito, A., Marelli, L., Penner, J. E., Putaud, J.-P., Textor, C., Schulz, M., van der Werf, G. R., and Wilson, J.: Emissions of primary aerosol and precursor gases in the years 2000 and 1750 prescribed data-sets for AeroCom, Atmos. Chem. Phys., 6, 4321-4344, doi:10.5194/acp-64321-2006, 2006.

Doherty, S. J., Dang, C., Hegg, D. A., Zhang, R., and Warren, S. G.: Black carbon and other light-absorbing particles in snow of central North America, J. Geophys. Res.-Atmos., 119, 1280712831, doi:10.1002/2014JD022350, 2014.

Duan, A. M. and Wu, G. X.: Weakening trend in the atmospheric heat source over the Tibetan Plateau during recent decades. Part I: Observations, J. Clim., 21, 3149-3164, doi:10.1175/2007JCLI1912.1, 2008.

Duan, A., Wu, G., Zhang, Q., and Liu, Y.: New proofs of the recent climate warming over the Tibetan Plateau as a result of the increasing greenhouse gases emissions, Chin. Sci. Bull., 51, 13961400, doi:10.1007/s11434-006-1396-6, 2006.

Flanner, M. G., Zender, C. S., Randerson, J. T., and Rasch, P. J.: Present day climate forcing and response from black carbon in snow, J. Geophys. Res., 112, D11202, doi:10.1029/2006JD008003, 2007.
Flanner, M. G., Zender, C. S., Hess, P. G., Mahowald, N. M., Painter, T. H., Ramanathan, V., and Rasch, P. J.: Springtime warming and reduced snow cover from carbonaceous particles, Atmos. Chem. Phys., 9, 2481-2497, doi:10.5194/acp-9-24812009, 2009.

Gettelman, A., Liu, X., Ghan, S. J., Morrison, H., Park, S., Conley, A. J., Klein, S. A., Boyle, J., Mitchell, D. L., and Li, J. L. F.: Global simulations of ice nucleation and ice supersaturation with an improved cloud scheme in the Community Atmosphere Model, J. Geophys. Res., 115, D18216, doi:10.1029/2009jd013797, 2010.

Ginot, P., Dumont, M., Lim, S., Patris, N., Taupin, J.-D., Wagnon, P., Gilbert, A., Arnaud, Y., Marinoni, A., Bonasoni, P., and Laj, P.: A 10 year record of black carbon and dust from a Mera Peak ice core (Nepal): variability and potential impact on melting of Himalayan glaciers, The Cryosphere, 8, 1479-1496, doi:10.5194/tc-8-1479-2014, 2014.

Hadley, O. L. and Kirchstetter, T. W.: Black-carbon reduction of snow albedo, Nat. Clim. Change, 2, 437-440, 2012.

Hall, A. and Qu, X.: Using the current seasonal cycle to constrain snow albedo feedback in future climate change, Geophys. Res. Lett., 33, L03502, doi:10.1029/2005GL025127, 2006.

Hall, D. K., Riggs G. A., and Salomonson V. V.: updated monthly. MODIS/TERRA Snow Cover Monthly L3 Global 0.05Deg CMG V005, [2001], Boulder, CO, National Snow and Ice Data Center. Digital Media, distributed in netCDF format by the Integrated Climate Data Center (ICDC, available at: http://icdc.zmaw.de, last access: 26 December 2014, University of Hamburg, Hamburg, Germany), 2006.

Hansen, J. and Nazarenko, L.: Soot climate forcing via snow and ice albedos, P. Natl. Acad. Sci. USA, 101, 423-428, doi:10.1073/pnas.2237157100, 2004.

Hansen, J., Sato, M., Ruedy, R., Nazarenko, L., Lacis, A., Schmidt, G. A., Russell, G., Aleinov, I., Bauer, M., Bauer, S., Bell, N., Cairns, B., Canuto, V., Chandler, M., Cheng, Y., Del Genio, A., Faluvegi, G., Fleming, E., Friend, A., Hall, T., Jackman, C., Kelley, M., Kiang, N., Koch, D., Lean, J., Lerner, J., Lo, K., Menon, S., Miller, R., Minnis, P., Novakov, T., Oinas, V., Perlwitz, Ja., Perlwitz, Ju., Rind, D., Romanou, A., Shindell, D., Stone, P., Sun, S., Tausnev, N., Thresher, D., Wielicki, B., Wong, T., Yao, M., and Zhang, S.: Efficacy of climate forcings, J. Geophys. Res., 110, D18104, doi:10.1029/2005JD005776, 2005.

Huang, J., Minnis, P., Yi, Y., Tang, Q., Wang, X., Hu, Y., Liu, Z., Ayers, K., Trepte, C., and Winker, D.: Summer dust aerosols detected from CALIPSO over the Tibetan Plateau, Geophys. Res. Lett., 34, L18805, doi:10.1029/2007GL029938, 2007.

Huang, J., Fu, Q., Zhang, W., Wang, X., Zhang, R., Ye, H., and Warren, S. G.: Dust and black carbon in seasonal snow across Northern China, B. Am. Meteorol. Soc., 92, 175-181, doi:10.1175/2010BAMS3064.1, 2011.

Hurrell, J. W., Holland, M. M., Ghan, S., Lamarque, J.-F., Lawrence, D., Lipscomb, W. H., Mahowald, N., Marsh, D., Rasch, P., Bader, D., Collins, W. D., Gent, P. R., Hack, J. J., Kiehl, J., Kushner, P., Large, W. G., Marshall, S., Vavrus, S., and Vertenstein, M.: The Community Earth System Model: A Framework for Collaborative Research, B. Am. Meteorol. Soc., 94, 1339-1360, doi:10.1175/BAMS-D-12-00121, 2013. 
Immerzeel, W., VanBeek L. P. H., and Bierkens, M. F. P.: Climate Change Will Affect the Asian Water Towers, Science, 328, 13821385, doi:10.1126/science.1183188, 2010.

Jacobson, M. Z.: Climate response of fossil fuel and biofuel soot, accounting for soot's feedback to snow and sea ice albedo and emissivity, J. Geophys. Res., 109, D21201, doi:10.1029/2004JD004945, 2004.

Jiao, C., Flanner, M. G., Balkanski, Y., Bauer, S. E., Bellouin, N., Berntsen, T. K., Bian, H., Carslaw, K. S., Chin, M., De Luca, N., Diehl, T., Ghan, S. J., Iversen, T., Kirkevåg, A., Koch, D., Liu, X., Mann, G. W., Penner, J. E., Pitari, G., Schulz, M., Seland, Ø., Skeie, R. B., Steenrod, S. D., Stier, P., Takemura, T., Tsigaridis, K., van Noije, T., Yun, Y., and Zhang, K.: An AeroCom assessment of black carbon in Arctic snow and sea ice, Atmos. Chem. Phys., 14, 2399-2417, doi:10.5194/acp-14-2399-2014, 2014.

Kang, S., Wake, C., Qin, D., Mayewski, P. A., and Yao, T.: Monsoon and dust signals recorded in Dasuopu glacier, Tibetan Plateau, J. Glaciol., 46, 222-226, 2000.

Kang, S., Wei, X., You, Q., Flugel, W., Pepin, N., and Yao, T.: Review of climate and cryospheric change in the Tibetan Plateau, Environ. Res. Lett., 5, 015101, doi:10.1088/17489326/5/1/015101, 2010.

Kaser, G., Grosshauser, M., and Marzeion, B.: Contribution of glaciers to water availability in different climate regimes, P. Natl. Acad. Sci. USA, 107, 20223-20227, doi:10.1073/pnas.1008162107, 2010

Kaspari, S. D., Schwikowski, M., Gysel, M., Flanner, M. G., Kang, S., Hou, S., and Mayewski, P. A.: Resent increase in black carbon concentrations from a Mt. Everest ice core spanning 1860-2000 AD, Geophys. Res. Lett., 38, L04703, doi:10.1029/2010GL046096, 2011.

Kopacz, M., Mauzerall, D. L., Wang, J., Leibensperger, E. M., Henze, D. K., and Singh, K.: Origin and radiative forcing of black carbon transported to the Himalayas and Tibetan Plateau, Atmos. Chem. Phys., 11, 2837-2852, doi:10.5194/acp-11-28372011, 2011.

Lamarque, J.-F., Bond, T. C., Eyring, V., Granier, C., Heil, A., Klimont, Z., Lee, D., Liousse, C., Mieville, A., Owen, B., Schultz, M. G., Shindell, D., Smith, S. J., Stehfest, E., Van Aardenne, J., Cooper, O. R., Kainuma, M., Mahowald, N., McConnell, J. R., Naik, V., Riahi, K., and van Vuuren, D. P.: Historical (1850-2000) gridded anthropogenic and biomass burning emissions of reactive gases and aerosols: methodology and application, Atmos. Chem. Phys., 10, 7017-7039, doi:10.5194/acp10-7017-2010, 2010.

Lamarque, J.-F., Emmons, L. K., Hess, P. G., Kinnison, D. E., Tilmes, S., Vitt, F., Heald, C. L., Holland, E. A., Lauritzen, P. H., Neu, J., Orlando, J. J., Rasch, P. J., and Tyndall, G. K.: CAM-chem: description and evaluation of interactive atmospheric chemistry in the Community Earth System Model, Geosci. Model Dev., 5, 369-411, doi:10.5194/gmd-5-369-2012, 2012.

Lau, K. M., Kim, M. K., and Kim, K. M.: Asian monsoon anomalies induced by aerosol direct forcing: the role of the Tibetan Plateau, Clim. Dyn., 26, 855-664, 2006.

Lau, K.-M., Kim, M. K., Kim, K.-M., and Lee, W. S.: Enhanced surface warming and accelerated snow melt in the Himalayas and Tibetan Plateau induced by absorbing aerosols, Environ. Res. Lett., 5, 025204, doi:10.1088/1748-9326/5/2/025204, 2010.
Lee, Y. H., Lamarque, J.-F., Flanner, M. G., Jiao, C., Shindell, D. T., Berntsen, T., Bisiaux, M. M., Cao, J., Collins, W. J., Curran, M., Edwards, R., Faluvegi, G., Ghan, S., Horowitz, L. W., McConnell, J. R., Ming, J., Myhre, G., Nagashima, T., Naik, V., Rumbold, S. T., Skeie, R. B., Sudo, K., Takemura, T., Thevenon, F., Xu, B., and Yoon, J.-H.: Evaluation of preindustrial to presentday black carbon and its albedo forcing from Atmospheric Chemistry and Climate Model Intercomparison Project (ACCMIP), Atmos. Chem. Phys., 13, 2607-2634, doi:10.5194/acp13-2607-2013, 2013.

Li, X., Cheng, G., Jin, H., Kang, E., Che, T., Jin, R., Wu, L., Nan, Z., Wang, J., and Shen, Y.: Cryospheric change in China, Global Planet. Change, 62, 210-218, 2008.

Liu, X., Easter, R. C., Ghan, S. J., Zaveri, R., Rasch, P., Shi, X., Lamarque, J.-F., Gettelman, A., Morrison, H., Vitt, F., Conley, A., Park, S., Neale, R., Hannay, C., Ekman, A. M. L., Hess, P., Mahowald, N., Collins, W., Iacono, M. J., Bretherton, C. S., Flanner, M. G., and Mitchell, D.: Toward a minimal representation of aerosols in climate models: description and evaluation in the Community Atmosphere Model CAM5, Geosci. Model Dev., 5, 709-739, doi:10.5194/gmd-5-709-2012, 2012.

Liu, Z., Liu, D., Huang, J., Vaughan, M., Uno, I., Sugimoto, N., Kittaka, C., Trepte, C., Wang, Z., Hostetler, C., and Winker, D.: Airborne dust distributions over the Tibetan Plateau and surrounding areas derived from the first year of CALIPSO lidar observations, Atmos. Chem. Phys., 8, 5045-5060, doi:10.5194/acp-85045-2008, 2008.

Lu, Z., Streets, D. G., Zhang, Q., and Wang, S.: A novel backtrajectory analysis of the origin of black carbon transported to the Himalayas and Tibetan Plateau during 1996-2010, Geophys Res. Lett., 39, L01809, doi:10.1029/2011GL049903, 2012.

Ma, P.-L., Rasch, P. J., Wang, H., Zhang, K., Easter, R. C., Tilmes, S., Fast, J. D., Liu, X., Yoon, J.-H., and Lamarque, J.-F.: The role of circulation features on black carbon transport into the Arctic in the Community Atmosphere Model Version 5 (CAM5), J. Geophys. Res.-Atmos., 118, 4657-4669, 2013.

Manabe, S. and Terpstra, T. B.: The effects of mountains on the general circulation of the atmosphere as identified by numerical experiments, J. Atmos. Sci., 31, 3-42, 1974.

Marinoni, A., Cristofanelli, P., Laj, P., Duchi, R., Calzolari, F., Decesari, S., Sellegri, K., Vuillermoz, E., Verza, G. P., Villani, P., and Bonasoni, P.: Aerosol mass and black carbon concentrations, a two year record at NCO-P (5079 m, Southern Himalayas), Atmos. Chem. Phys., 10, 8551-8562, doi:10.5194/acp-10-85512010, 2010.

Marinoni, A., Cristofanelli, P., Laj, P., Duchi, R., Putero, D., Calzolari, F., Landi, T. C., Vuillermoz, E., Maione, M., and Bonasoni, P.: High black carbon and ozone concentrations during pollution transport in the Himalayas: Five years of continuous observations at NCO-P global GAW station, J. Environ. Sci., 25, 1618-1625, doi:10.1016/S1001-0742(12)60242-3, 2013.

Ménégoz, M., Krinner, G., Balkanski, Y., Boucher, O., Cozic, A., Lim, S., Ginot, P., Laj, P., Gallée, H., Wagnon, P., Marinoni, A., and Jacobi, H. W.: Snow cover sensitivity to black carbon deposition in the Himalayas: from atmospheric and ice core measurements to regional climate simulations, Atmos. Chem. Phys., 14, 4237-4249, doi:10.5194/acp-14-4237-2014, 2014.

Menon, S., Koch, D., Beig, G., Sahu, S., Fasullo, J., and Orlikowski, D.: Black carbon aerosols and the third polar ice cap, Atmos. 
Chem. Phys., 10, 4559-4571, doi:10.5194/acp-10-4559-2010, 2010.

Ming, J., Cachier, H., Xiao, C., Qin, D., Kang, S., Hou, S., and $\mathrm{Xu}, \mathrm{J} .:$ Black carbon record based on a shallow Himalayan ice core and its climatic implications, Atmos. Chem. Phys., 8, 13431352, doi:10.5194/acp-8-1343-2008, 2008.

Ming, J., Xiao, C. D., Cachier, H., Qin, D. H., Qin, X., Li, Z. Q., and $\mathrm{Pu}, \mathrm{J}$. C.: Black carbon (BC) in the snow of glaciers in west China and its potential effects on albedos, Atmos. Res., 92, 114123, doi:10.1016/j.atmosres.2008.09.007, 2009.

Ming, J., Xiao C., Sun J., Kang S., and Bonasoni P.: Carbonaceous particles in the atmosphere and precipitation of the Nam Co region, central Tibet, J. Environ. Sci., 22, 1748-1756, doi:10.1016/S1001-0742(09)60315-6, 2010.

Ming, J., Xiao, C., Du, Z., and Yang, X.: An overview of black carbon deposition in High Asia glaciers and its impacts on radiation balance, Adv. Water Resour., 55, 80-87, 2013.

Moorthy, K. K., Beegum, S. N., Srivastava, N., Satheesh, S. K., Chin, M., Blond, N., Babu, S. S., and Singh, S.: Performance evaluation of chemistry transport models over India, Atmos. Environ., 71, 210-225, 2013.

Neale, R. B., Chen, C.-C., Gettelman, A., Lauritzen, P. H., Park, S., Williamson, D. L., Conley, A. J., Garcia, R., Kinnison, D., Lamarque, J.-F., Marsh, D., Mills, M., Smith, A. K., Tilmes, S., Vitt, F., Cameron-Smith, P., Collins, W. D., Iacono, M. J., Easter, R. C., Ghan, S. J., Liu, X., Rasch, P. J., and Taylor, M. A.: Description of the NCAR Community Atmosphere Model (CAM 5.0), NCAR/TN-486 + STR, available at: http://www.cesm.ucar. edu/models/cesm1.0/cam/docs/description/cam5_desc.pdf (last access: 26 December 2014), 2012.

Ohara, T., Akimoto, H., Kurokawa, J., Horii, N., Yamaji, K., Yan, $\mathrm{X}$., and Hayasaka, T.: An Asian emission inventory of anthropogenic emission sources for the period 1980-2020, Atmos. Chem. Phys., 7, 4419-4444, doi:10.5194/acp-7-4419-2007, 2007.

Petzold, A., Ogren, J. A., Fiebig, M., Laj, P., Li, S.-M., Baltensperger, U., Holzer-Popp, T., Kinne, S., Pappalardo, G., Sugimoto, N., Wehrli, C., Wiedensohler, A., and Zhang, X.-Y.: Recommendations for reporting "black carbon" measurements, Atmos. Chem. Phys., 13, 8365-8379, doi:10.5194/acp-13-83652013, 2013.

Prasad, A. K. and Singh, R. P.: Changes in Himalayan Snow and Glacier Cover Between 1972 and 2000, Eos Trans. AGU, 88, 326-326, doi:10.1029/2007EO330002, 2007.

$\mathrm{Pu}, \mathrm{Z}$., Xu, L., and Salomonson, V. V.: MODIS/Terra observed seasonal variations of snow cover over the Tibetan Plateau, Geophys. Res. Lett., 34, L06706, doi:10.1029/2007GL029262, 2007.

Qian, Y., Flanner, M. G., Leung, L. R., and Wang, W.: Sensitivity studies on the impacts of Tibetan Plateau snowpack pollution on the Asian hydrological cycle and monsoon climate, Atmos. Chem. Phys., 11, 1929-1948, doi:10.5194/acp-11-19292011, 2011.

Qian, Y., Wang, H., Zhang, R., Flanner, M. G., and Rasch, P. J.: A sensitivity study on modeling black carbon in snow and its radiative forcing over the Arctic and Northern China, Environ. Res. Lett., 9, 064001, doi:10.1088/1748-9326/9/6/064001, 2014.

Qian, Y., Yasunari, T. J., Doherty, S. J., Flanner, M. G., Lau, K. M., Ming, J., Wang, H., Wang, M., Warren, S. G., and Zhang, R.: Light-absorbing particles in snow and ice: measurement and modeling of climatic and hydrological impact, Adv. Atmos. Sci., 32, 64-91 doi:10.1007/s00376-014-0010-0, 2015.

Qin, D., Liu, S., and Li, P.: Snow cover distribution, variability, and response to climate change in western China, J. Clim., 19, 18201833, 2006.

Qiu, J.: China: the third pole, Nature News, 454, 393-396, 2008.

Ram, K., Sarin, M. M., and Hegde, P.: Long-term record of aerosol optical properties and chemical composition from a high-altitude site (Manora Peak) in Central Himalaya, Atmos. Chem. Phys., 10, 11791-11803, doi:10.5194/acp-10-11791-2010, 2010.

Ramanathan, V., Ramana, M. V., Roberts, G., Kim, D., Corrigan, C., Chung, C., and Winker, D.: Warming trends in Asia amplified by brown clouds solar absorption, Nature, 448, 575-578, 2007.

Rasch, P. J., Mahowald, N. M., and Eaton, B. E.: Representations of transport, convection, and the hydrological cycle in chemical transport models: Implications for the modeling of short-lived and soluble species, J. Geophys. Res., 102, 28127-28138, 1997.

Ren, J., Jing, Z., Pu, J., and Qin, X.: Glaciers variations and climate change in the central Himalaya over the past few decades, Ann. Glaciol., 43, 218-222, 2006.

Rienecker, M. M., Suarez, M. J., Gelaro, R., Todling, R., Bacmeister, J., Liu, E., Bosilovich, M. G., Schubert, S. D., Takacs, L., Kim, G.-K., Bloom, S., Chen, J., Collins, D., Conaty, A., da Silva, A., Gu,W., Joiner, J., Koster, R. D., Lucchesi, R., and Molod, A.: MERRA - NASA's Modern-Era Retrospective Analysis for Research and Applications, J. Clim., 24, 3624-3648, 2011.

Shindell, D. T., Chin, M., Dentener, F., Doherty, R. M., Faluvegi, G., Fiore, A. M., Hess, P., Koch, D. M., MacKenzie, I. A., Sanderson, M. G., Schultz, M. G., Schulz, M., Stevenson, D. S., Teich, H., Textor, C., Wild, O., Bergmann, D. J., Bey, I., Bian, H., Cuvelier, C., Duncan, B. N., Folberth, G., Horowitz, L. W., Jonson, J., Kaminski, J. W., Marmer, E., Park, R., Pringle, K. J., Schroeder, S., Szopa, S., Takemura, T., Zeng, G., Keating, T. J., and Zuber, A.: A multi-model assessment of pollution transport to the Arctic, Atmos. Chem. Phys., 8, 5353-5372, doi:10.5194/acp-85353-2008, 2008.

Singh, P. and Bengtsson, L.: Hydrological sensitivity of a large Himalayan basin to climate change, Hydrol. Process., 18, 23632385, 2004.

Taylor, K. E., Stouffer, R. J., and Meehl, G. A.: An Overview of CMIP5 and the Experiment Design, B. Am. Meteorol. Soc., 93, 485-498, doi:10.1175/BAMS-D-11-00094.1, 2012.

Wang, B., Bao, Q., Hoskins, B., Wu, G., and Liu, Y.: Tibetan Plateau warming and precipitation changes in East Asia, Geophys. Res. Lett., 35, L14702, doi:10.1029/2008GL034330, 2008.

Wang, H., Easter, R. C., Rasch, P. J., Wang, M., Liu, X., Ghan, S. J., Qian, Y., Yoon, J.-H., Ma, P.-L., and Vinoj, V.: Sensitivity of remote aerosol distributions to representation of cloud-aerosol interactions in a global climate model, Geosci. Model Dev., 6, 765-782, doi:10.5194/gmd-6-765-2013, 2013.

Wang, H., Rasch, P. J., Easter, R. C., Singh, B., Zhang, R., Ma, P. L., Qian, Y., and Beagley, N.: Using an explicit emission tagging method in global modeling of source-receptor relationships for black carbon in the Arctic: Variations, Sources and Transport pathways, J. Geophys. Res.-Atmos., 119, 12888-12909, doi:10.1002/2014JD022297, 2014.

Wang, M., Xu, B., Cao, J., Tie, X., Wang, H., Zhang, R., Qian, Y., Rasch, P. J., Zhao, S., Wu, G., Zhao, H., Joswiak, D. R., Li, J., 
and Xie, Y.: Carbonaceous aerosols recorded in a southeastern Tibetan glacier: analysis of temporal variations and model estimates of sources and radiative forcing, Atmos. Chem. Phys., 15, 1191-1204, doi:10.5194/acp-15-1191-2015, 2015.

Wang, X., Doherty, S. J., and Huang, J.: Black carbon and other light-absorbing impurities in snow across Northern China, J. Geophys. Res. Atmos., 118, 1471-1492, doi:10.1029/2012JD018291, 2013.

Warren, S. G. and Wiscombe, W. J.: A model for the spectral albedo of snow. II: Snow containing atmospheric aerosols, J. Atmos. Sci., 37, 2734-2745, 1980.

Warren, S. G. and Wiscombe, W. J.: Dirty snow after nuclear war, Nature, 313, 469-470, 1985.

Wu, G., Liu, Y., He, B., Bao, Q., Duan, A., and Jin, F.-F.: Thermal controls on the Asian summer monsoon, Sci. Rep., 2, 404, doi:10.1038/srep00404, 2012.

Xia, X. G., Zong, X. M., Cong, Z. Y., Chen, H. B., Kang, S. C., and Wang, P. C.: Baseline continental aerosol over the central Tibetan plateau and a case study of aerosol transport from South Asia, Atmos. Environ., 45, 7370-7378, 2011.

Xu, B., Cao, J., Hansen, J., Yao, T., Joswiak, D. R., Wang, N.,Wu, G., Wang, M., Zhao, H., Yang, W., Liu, X., and He, J.: Black soot and the survival of Tibetan glaciers, P. Natl. Acad. Sci. USA, 106, 22114-22118, 2009.

Xu, X., Lu, C., Shi, X., and Gao, S.: World water tower: An atmospheric perspective, Geophys. Res. Lett., 35, L20815, doi:10.1029/2008GL035867, 2008.

Yanai, M., Li, C., and Song, Z.: Seasonal heating of the Tibetan Plateau and its effects on the evolution of the Asian summer monsoon, J. Meteorol. Soc. Jpn., 70, 319-351, 1992.

Yao, T., Pu, J., Lu, A., Wang, Y., and Yu, W.: Recent glacial retreat and its impact on hydrological processes on the Tibetan Plateau, China, and surrounding regions, Arct. Antarct. Alp. Res., 39, 642-650, 2007.

Yao, T., Thompson, L., Yang, W., Yu, W., Gao, Y., Guo, X., Yang, X., Duan, K., Zhao, H., Xu, B., Pu, J., Lu, A., Xiang, Y., Kattel, D. B., and Joswiak, D.: Different glacier status with atmospheric circulations in Tibetan Plateau and surroundings, Nat. Clim. Change, 2, 663-667, doi:10.1038/nclimate1580, 2012.
Yasunari, T. J., Bonasoni, P., Laj, P., Fujita, K., Vuillermoz, E., Marinoni, A., Cristofanelli, P., Duchi, R., Tartari, G., and Lau, K.-M.: Estimated impact of black carbon deposition during premonsoon season from Nepal Climate Observatory - Pyramid data and snow albedo changes over Himalayan glaciers, Atmos. Chem. Phys., 10, 6603-6615, doi:10.5194/acp-10-6603-2010, 2010.

Ye, D. and Gao, Y.: Meteorology of the Qinghai-Xizang Plateau, Chinese Science Press, Beijing, 1979.

Ye, D. and Wu, G.: The role of the heat source of the Tibetan Plateau in the general circulation, Meteorol. Atmos. Phys., 67, 181-198, doi:10.1007/BF01277509, 1998.

Ye, H., Zhang, R., Shi, J., Huang, J., Warren, S. G., and Fu, Q.: Black carbon in seasonal snow across northern Xinjiang in northwestern China, Environ. Res. Lett. 7, 044002, doi:10.1088/17489326/7/4/044002, 2012.

Yeh, T., Lo, S., and Chu, P.: The wind structure and heat balance in the lower troposphere over Tibetan Plateau and its surrounding, Acta Meteor. Sinica, 28, 108-121, 1957.

Zhang, R., Hegg, D. A., Huang, J., and Fu, Q.: Source attribution of insoluble light-absorbing particles in seasonal snow across northern China, Atmos. Chem. Phys., 13, 6091-6099, doi:10.5194/acp-13-6091-2013, 2013.

Zhang, X. Y., Arimoto, R., Cao, J. J., An, Z. S., and Wang, D.: Atmospheric dust aerosol over the Tibetan Plateau, J. Geophys. Res., 106, 18471-18476, 2001.

Zhao, S., Ming, J., Xiao, C., Sun, W., and Qin, X.: A preliminary study on measurements of black carbon in the atmosphere of northwest Qilian Shan, J. Environ. Sci., 24, 152-159, doi:10.1016/S1001-0742(11)60739-0, 2012.

Zhao, Z., Cao, J., Shen, Z., Xu, B., Chen, L.-W. A., Ho, K., Han, Y., Zhu, C., and Liu, S.: Aerosol particles at a high-altitude site on the Southeast Tibetan Plateau, China: implications for pollution transport from South Asia, J. Geophys. Res.-Atmos., 118 , 11360-11375, doi:10.1002/jgrd.50599, 2013. 